\title{
REDC Process Instrumentation Modernization Project
}

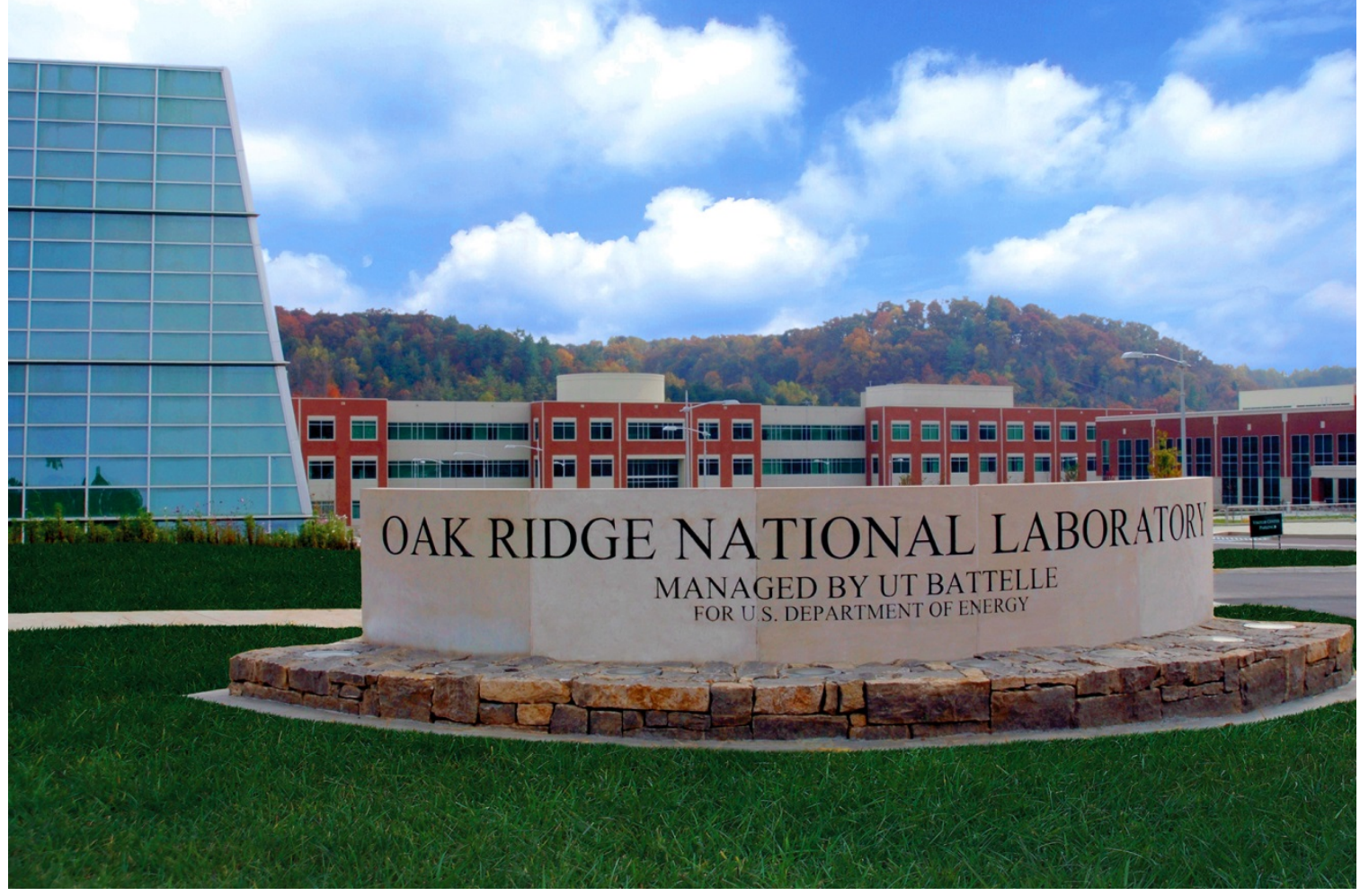
C. L. Britton
M. N. Ericson
G. L. Long
J. S. Neal
L. Fabris
M. Klein
G. Sullivan
S. Schrell

October 2021 


\title{
DOCUMENT AVAILABILITY
}

Reports produced after January 1, 1996, are generally available free via US Department of Energy (DOE) SciTech Connect.

\section{Website www.osti.gov}

Reports produced before January 1, 1996, may be purchased by members of the public from the following source:

\author{
National Technical Information Service \\ 5285 Port Royal Road \\ Springfield, VA 22161 \\ Telephone 703-605-6000 (1-800-553-6847) \\ TDD 703-487-4639 \\ Fax 703-605-6900 \\ E-mail info@ntis.gov \\ Website http://classic.ntis.gov/
}

Reports are available to DOE employees, DOE contractors, Energy Technology Data Exchange representatives, and International Nuclear Information System representatives from the following source:

Office of Scientific and Technical Information

PO Box 62

Oak Ridge, TN 37831

Telephone 865-576-8401

Fax 865-576-5728

E-mail reports@osti.gov

Website https://www.osti.gov/

This report was prepared as an account of work sponsored by an
agency of the United States Government. Neither the United States
Government nor any agency thereof, nor any of their employees, makes
any warranty, express or implied, or assumes any legal liability or
responsibility for the accuracy, completeness, or usefulness of any
information, apparatus, product, or process disclosed, or represents that
its use would not infringe privately owned rights. Reference herein to
any specific commercial product, process, or service by trade name,
trademark, manufacturer, or otherwise, does not necessarily constitute
or imply its endorsement, recommendation, or favoring by the United
States Government or any agency thereof. The views and opinions of
authors expressed herein do not necessarily state or reflect those of the
United States Government or any agency thereof. 
Electrification \& Energy Infrastructure Division Radioisotope Science and Technology Division Physics Division Integrated Operations Support Division Nonreactor Nuclear Facilities Division

\title{
REDC PROCESS INSTRUMENTATION MODERNIZATION PROJECT
}

\author{
C. L. Britton \\ M. N. Ericson \\ G. L. Long \\ J. S. Neal \\ L. Fabris \\ M. Klein \\ G. Sullivan \\ S. Schrell
}

October 2021

Prepared by OAK RIDGE NATIONAL LABORATORY

Oak Ridge, TN 37831-6283

managed by

UT-BATTELLE LLC

for the

US DEPARTMENT OF ENERGY

under contract DE-AC05-00OR2272 


\section{CONTENTS}

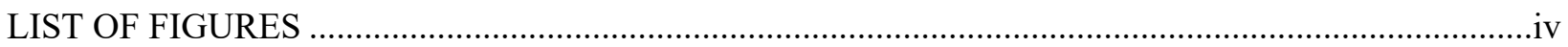

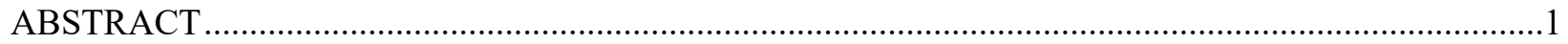

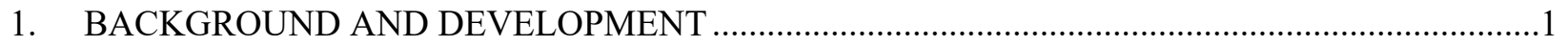

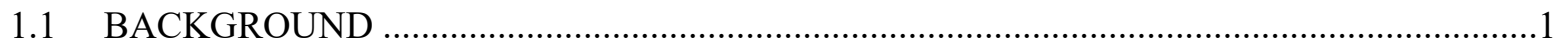

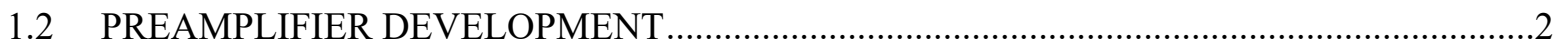

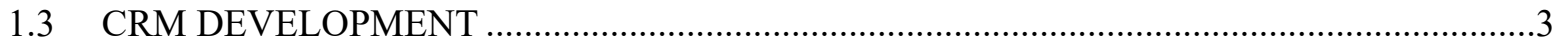

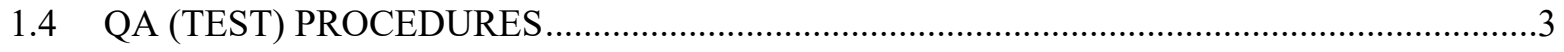

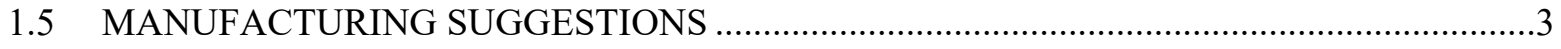

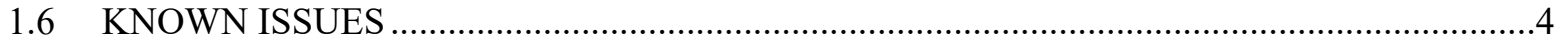

APPENDIX A. DETAILED SYSTEM AND ENVIRONMENT DESCRIPTION ….............................

APPENDIX B. PREAMPLIFIER TEST PROCEDURE, 09-14-2021, REV. A …..................................

APPENDIX C. CRM TEST PROCEDURE, 09-14-2021, REV. A …...............................................

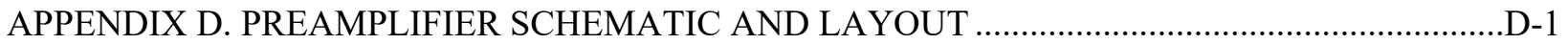

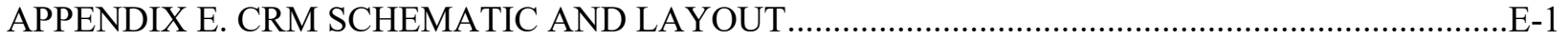




\section{LIST OF FIGURES}

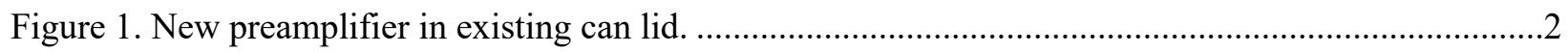

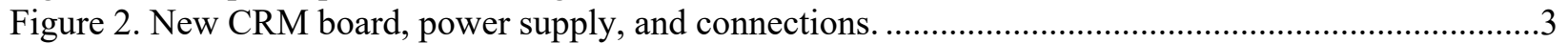

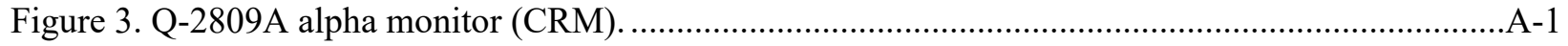

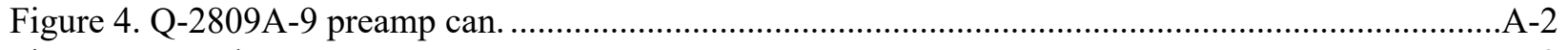

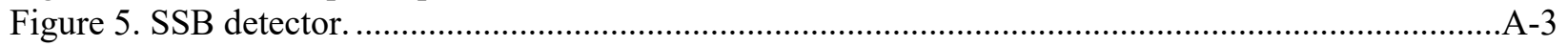

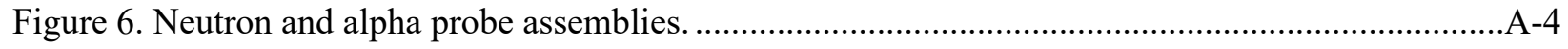

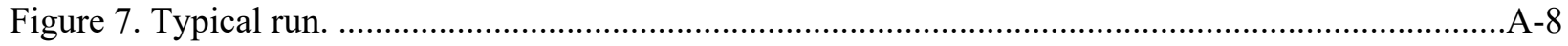

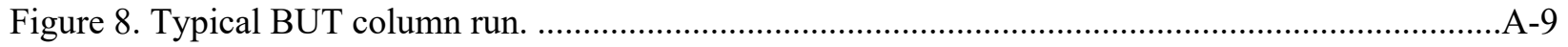




\begin{abstract}
Critical electronics used for isotopes production have become outdated and difficult to manufacture. In particular the alpha-particle and neutron detection electronics (commonly referred to as Q2809A-9 and 11) that are used to monitor effluent activity in ORNL Building 7920 were designed and deployed in 1966-1967. These electronics are still used, but some parts are no longer available for purchase. In addition, the printed circuit boards used in the Count Rate Monitor (CRM) module have no fabrication files or quality assurance (QA) documentation. Because of this, a project to modernize the modules to manufacture them with modern parts was undertaken. Both the preamplifier and CRM were modernized with new printed circuit boards and parts that are current catalog parts. In addition, QA documentation was generated, which allows the manufacturer to assure proper operation before delivery.
\end{abstract}

\title{
1. BACKGROUND AND DEVELOPMENT
}

\subsection{BACKGROUND}

The electronics were developed in 1966-1967 by the now disbanded ORNL Instrumentation and Controls Division for the express purpose of isotope monitoring. The instrumentation has been in constant use since that time. Approximately 10 of the CRM modules were originally built, and many more preamplifiers have been continuously built. Since the original build, only preamplifiers have continued to be fabricated and only the original CRMs have been used. A detailed description of the system and its environment is contained in Appendix A.

In 2003, a set of preamplifier modifications was implemented because some of the original parts were unavailable. Since then, the preamplifiers have continued to be fabricated and used, but parts are again becoming unavailable. Recently, it was decided that a redesign or modernization was required because the isotope program is growing, and more systems are needed. The following issues need to be addressed:

a. Cost

b. Operator training requirements

c. Preamplifier radiation resistance

Various approaches were considered for the development:

a. Redesign the original system using the same circuit topologies with modern parts

b. Redesign the system using as many off-the-shelf components as possible

c. Redesign the system using preamplifier photomultiplier tubes for radiation hardness

Approach " $\mathrm{b}$ " had already been attempted at the Radiochemical Engineering Development Center (REDC) before this development using ORTEC nuclear instrumentation modules. Because the preamplifiers needed were commercial, general-purpose items, they were expensive and not radiation resistant. In addition, the operation of the instrument chain was completely different from the existing system, and it was not clear that the results would be acceptable within a reasonable budget.

Approach "c" was promising except that extensive testing was likely to be required to choose the correct scintillator material or materials for both the alpha and neutron sources. Again, because of the unknowns in the required system, it was not clear that the results would be acceptable within a reasonable budget.

Approach "a" appeared to solve most problems, except for radiation resistance. The original preamps from 1967 were not radiation hard in the traditional sense but appeared to survive for a long period, 
perhaps years. Some of the reason for that is likely due to the choice of 1960's vintage transistors that had been tested by the Instrumentation and Controls Division but were no longer available in the original form.

Our decision was to use only two or three different transistors currently manufactured that will likely be available for the foreseeable future and use improved ceramic capacitors with some minor circuit design changes to enable to preamplifiers to be more economically manufactured with current technology. The results were to be a preamplifier that operates like the original but costs less and whose parts are easier to procure.

The same issues were considered for the CRM except there is no radiation exposure to the CRM. Several parts for the original are also unavailable, and the design decisions will be discussed later in this report.

\subsection{PREAMPLIFIER DEVELOPMENT}

Schematics for the original and 2003 model preamplifiers were available and carefully studied. The preamplifier is basically a charge-sensitive preamplifier with gain and filtering stages and a driver that outputs the signal to a cable. In 1966, there were no integrated circuits, so all of the circuitry was bipolar transistor. Detailed LTSpice simulations were performed on the circuit to ensure the topology was understood. LTSpice is a circuit simulator that allows analysis of transient, frequency, and direct current (DC) behavior. The circuit is not complicated but required simulation because transistor changes and printed circuit layout changes required simulations to ensure correct operation. Simulations revealed minor changes that were needed in the design.

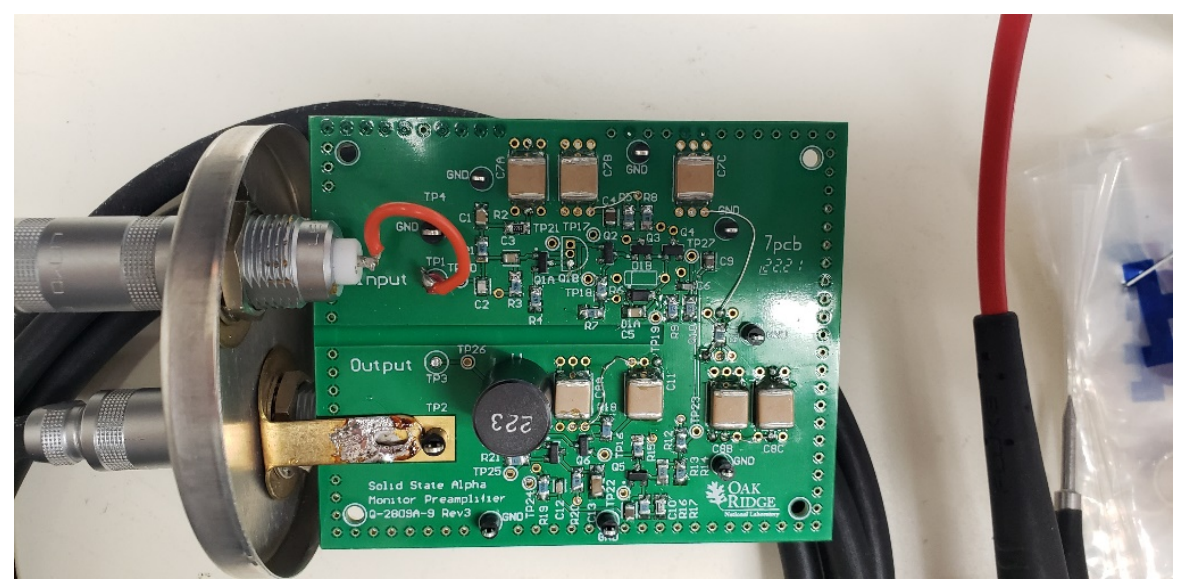

Figure 1. New preamplifier in existing can lid.

After the simulations were complete, a new printed circuit board (PCB) layout was undertaken. The decision was made after consultation with operations personnel that the original preamplifier can should be used because the cell access and in-cell mounting was best suited for the existing device. The new board was therefore the same width, but approximately two-thirds as long as the original board, which allowed the old can to be used. The layout was started by entering the revised schematic into a schematic capture/layout tool called Altium, which also allowed a bill of materials to be created for parts procurement. After review of the PCB, the boards (Rev. 3) were fabricated, and a board was assembled. The board was tested, but there were some manufacturing errors that were easily corrected and then refabricated (Rev. 4). We then built a new version of the board shown in Figure 1 and tested it on the bench. Both versions revealed the need for some minor circuit modifications, which were incorporated into the design to mitigate a high-frequency oscillation that was occurring in the original topology. Two 
prototypes were built and delivered to REDC for in-cell testing. A final layout version that incorporates the changes required will be delivered to REDC in preparation for a pilot run build.

\subsection{CRM DEVELOPMENT}

The CRM followed a similar development path regarding simulations of the circuitry but simulations could not be run on all of the circuitry because an input amplifier in the CRM comprised two obsolete germanium transistors, which had no available SPICE models. These were changed to silicon transistors, and simulations were performed; however, in lieu of a complete PCB layout, an existing CRM was taken, and transistors were removed and replaced in sections with available devices. Some minor redesign was needed for the obsolete germanium devices but for the most part, the circuit was unchanged.

Based on discussions with operators, some of the now unused functions of the original CRM were removed. An audio oscillator that audibly indicated rising and falling count rate was removed, as was an obsolete rate-indicating ballistic meter. The new design was placed into a rack-mounted enclosure powered by a modern, UL-approved DC power supply and is shown in Figure 2.

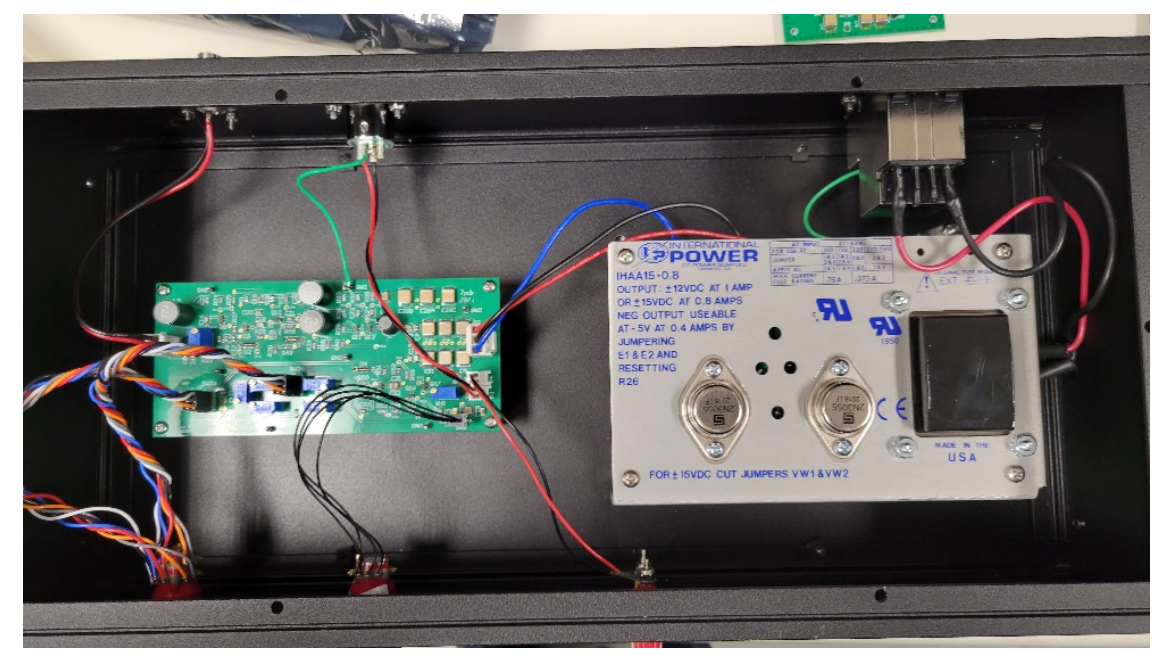

Figure 2. New CRM board, power supply, and connections.

\subsection{QA TEST PROCEDURES}

Fabrication documentation was also prepared during this development. For the old system, there had not been any testing instructions against which the preamplifiers were tested. We created a test procedure for the fabrication shop to be able to ensure that the devices are working properly after assembly. Also, because CRMs have not been built for more than 50 years, we created testing and calibration procedures, which were tested on an existing CRM with similar results. Those procedures are in Appendices B and C.

\subsection{MANUFACTURING SUGGESTIONS}

Since the scope of this project was to deliver prototypes and documentation, no production was planned. The suggested approach for the future deployment should include the following.

1. Preamplifier in situ testing. The preamplifiers have been thoroughly tested on the bench but have just recently been placed in a test cell at REDC. Some testing with both alpha and neutron probes should be finished before further fabrication is attempted. The outputs of the two prototype 
preamplifiers need to be inspected using an oscilloscope for both detectors to ensure no oscillation or anomalous operation.

2. CRM testing. The CRM was also bench tested and calibrated but also needs to be tested in situ with an experienced operator to ensure proper operation. In particular, there is no guidance about how the CRM gain setting should be adjusted with the new preamps and new internal components.

3. Pilot run. After testing and concurrence that the devices are operating properly, a pilot run should be undertaken. Final schematics, bills of material and layouts should be generated, and orders of 10 preamplifiers and 3 CRMs should be ordered. These should all be fabricated in accordance to the prototypes and tested in accordance to the test procedures. After deployment and in situ testing, modifications of the devices, and modifications of the new test procedures if needed, an appropriate fabrication run of the new devices can be pursued.

\subsection{KNOWN ISSUES}

1. Preamplifier oscillations. The original preamplifier topology after relay out exhibited a highfrequency $(50 \mathrm{MHz})$ oscillation likely due to the new transistors and improved layout. This was mitigated in the revised circuit. This needs to be monitored on the output of the preamplifiers being tested.

2. CRM high-rate performance. Because of the change in transistors, the CRM exhibited a reduction in high-rate range above $100,000 \mathrm{cps}$. This was mitigated and should easily exceed $350,000 \mathrm{cps}$. The same test showed an existing CRM box with approximately the same range.

3. CRM rate comparison. All testing on the new CRM has been using a fixed periodic known rate instead of a source that provided a Poisson-distributed random rate. To ensure accuracy, operators should continuously be aware of the comparison between old and new results. 


\section{APPENDIX A. DETAILED SYSTEM AND ENVIRONMENT DESCRIPTION}

\section{OBJECTIVE}

The portable alpha and neutron radiation instrument cabinet used in nuclear chemical processing in the Building 7920 hot cell cubicles was replaced with a new instrument cabinet with off-the-shelf nuclear instrumentation modules and a touch screen paperless recorder. The existing cabinet contains two ORNL Model Q-2809A solid-state alpha monitors and an out-of-production Linear Instrument Corporation twopen chart recorder. This system did not work.

\section{EXISTING RADIATION INSTRUMENTATION}

The Q-2809A monitors are count ratemeters (CRM) that were designed and built in 1966 by the disbanded Instrumentation and Controls Division at ORNL. The CRM is composed of a main chassis that contains power supply; power switch and pilot light; printed circuit board with discrete bipolar transistor amplifier, discriminator, and integrator circuitry; analog rate meter with range of $0-10$ counts per second (cps); five-decade range switch $(\times 1$ to $\times 10,000)$; three-position integrate time switch (short, medium, and long); loudspeaker with volume control; and calibrate push button. See Figure 3 below. On the rear of the chassis, there is a Bayonet Neill-Concelman (BNC) signal input jack and an Amphenol two-pin output connector that allows the monitor to be connected to a recorder (range 0-10 mV). See Figure 4 below of the Q-2809A-1, Solid State Alpha Monitor Circuit.

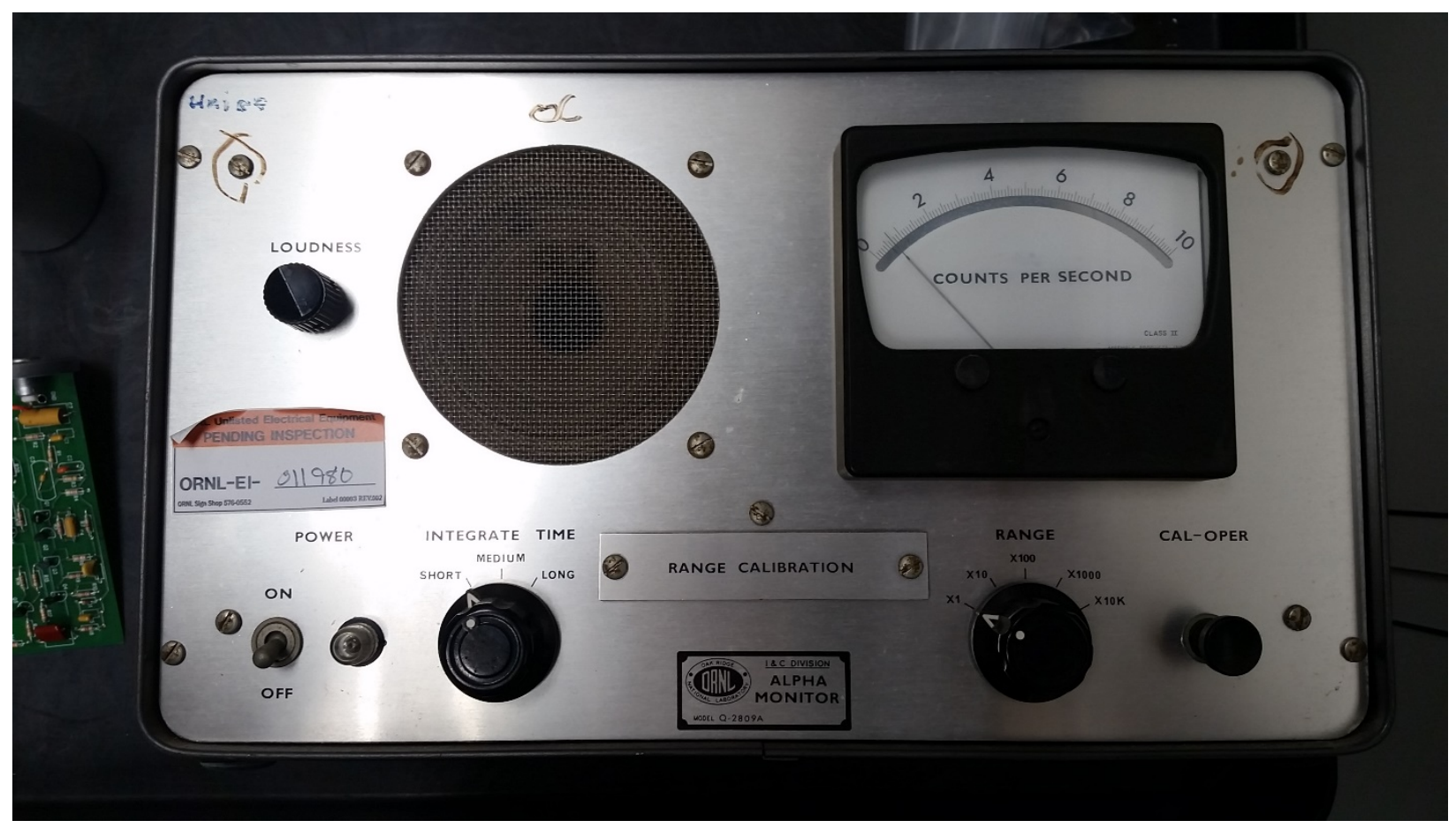

Figure 3. Q-2809A alpha monitor (CRM). 


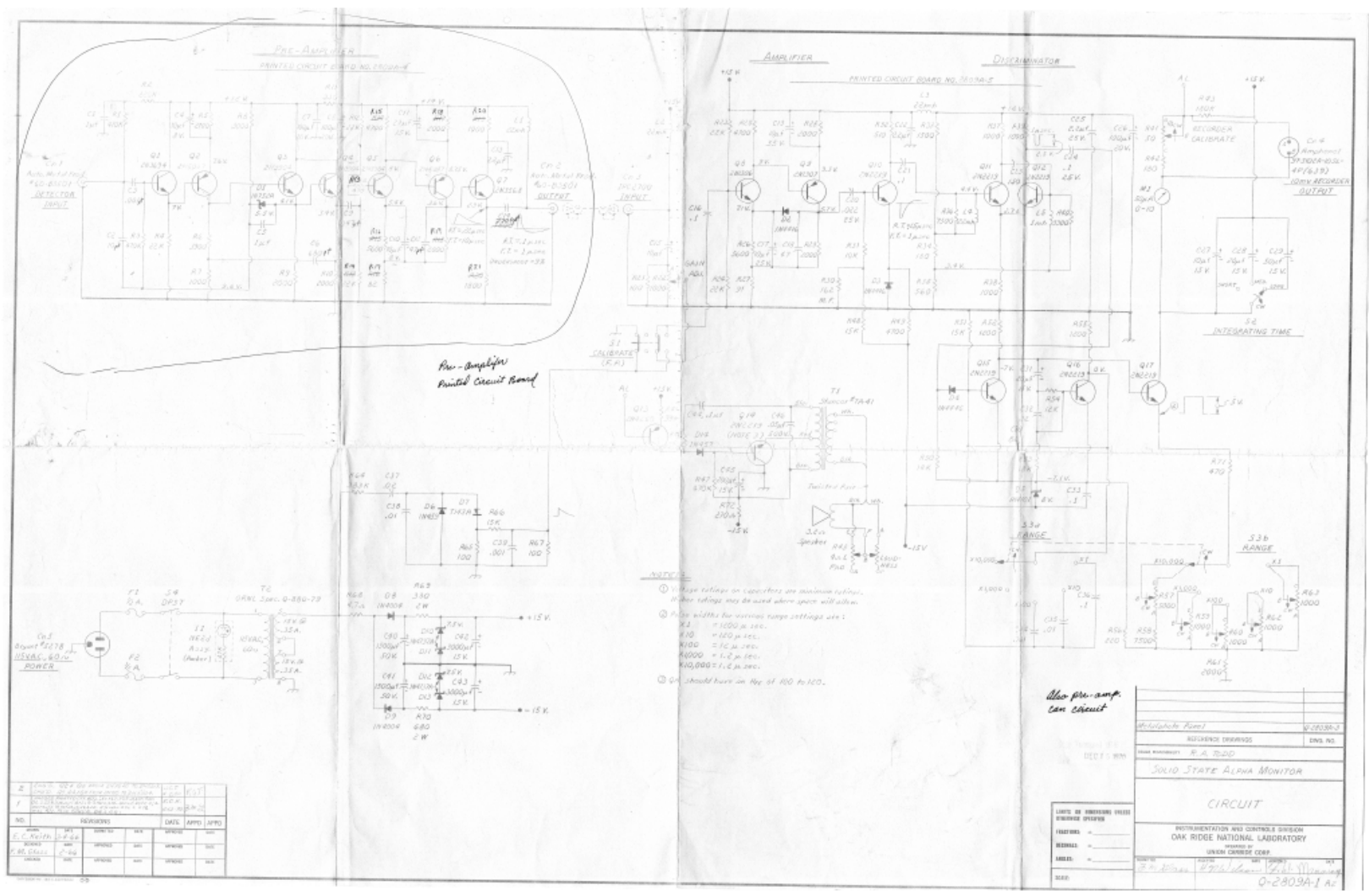

Figure 4. Q-2809A-1, Solid State Alpha Monitor Circuit.

This design also requires a separate Q2809A-9 preamplifier installed inside an aluminum cylinder located inside the cubicle that is commonly referred to as the Preamp Can (Figure 5). The Preamp Can has solidstate circuitry on a printed circuit board (PCB) that contains three stages of gain with a pulse shaper output. The circuit uses several bipolar transistors, resistors, capacitors, and inductors to amplify the small pulse signal output of the detector. The Preamp Cans have two single pin LEMO receptacles (jacks). One for input and the other for output. See Figure below. The Preamp Can was updated with a new PCB and updated parts in 2003. See Figure 6 Q-2809A-9 \& 11 PreampSch \& Parts. 


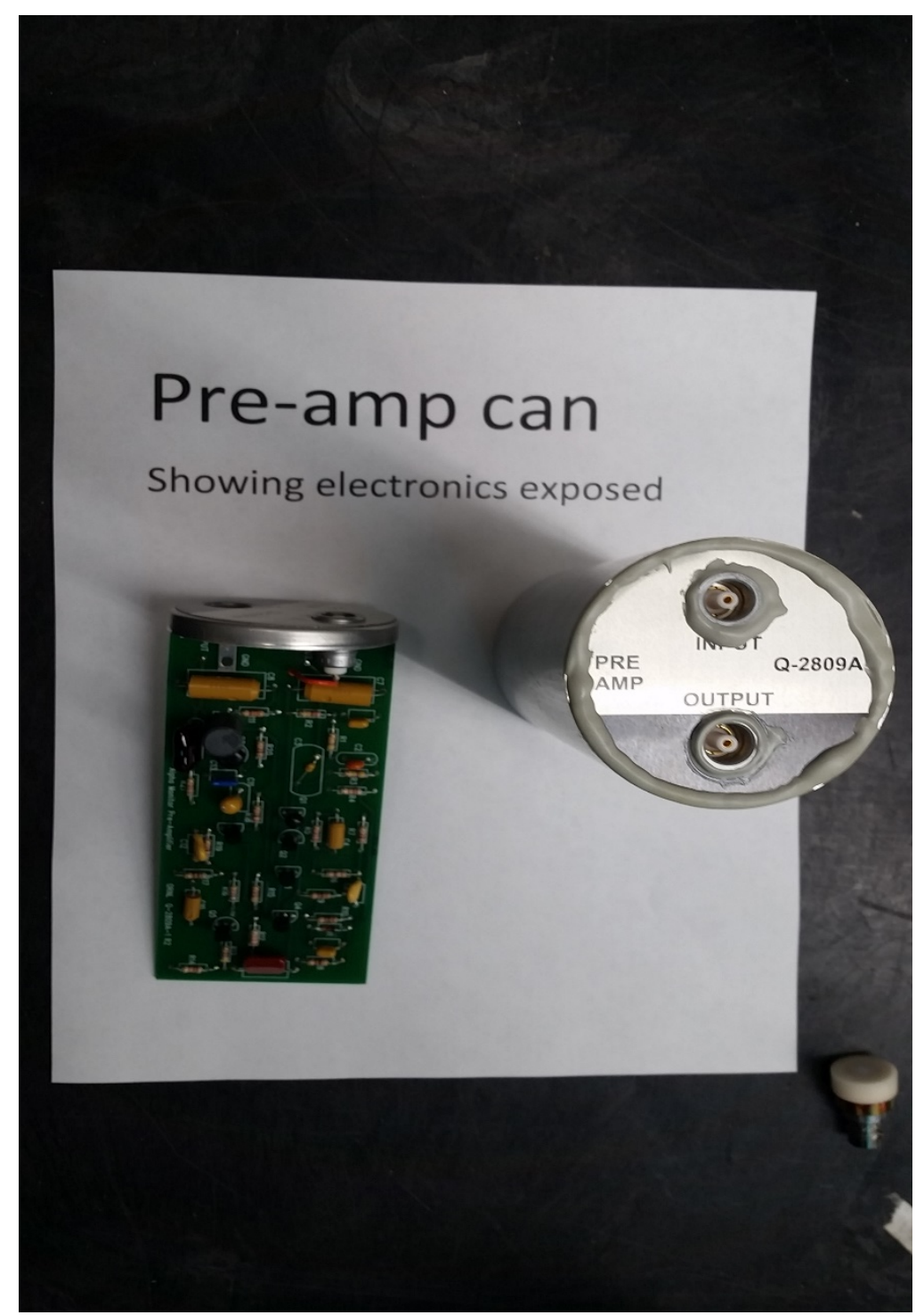

Figure 5. Q-2809A-9 preamp can. 


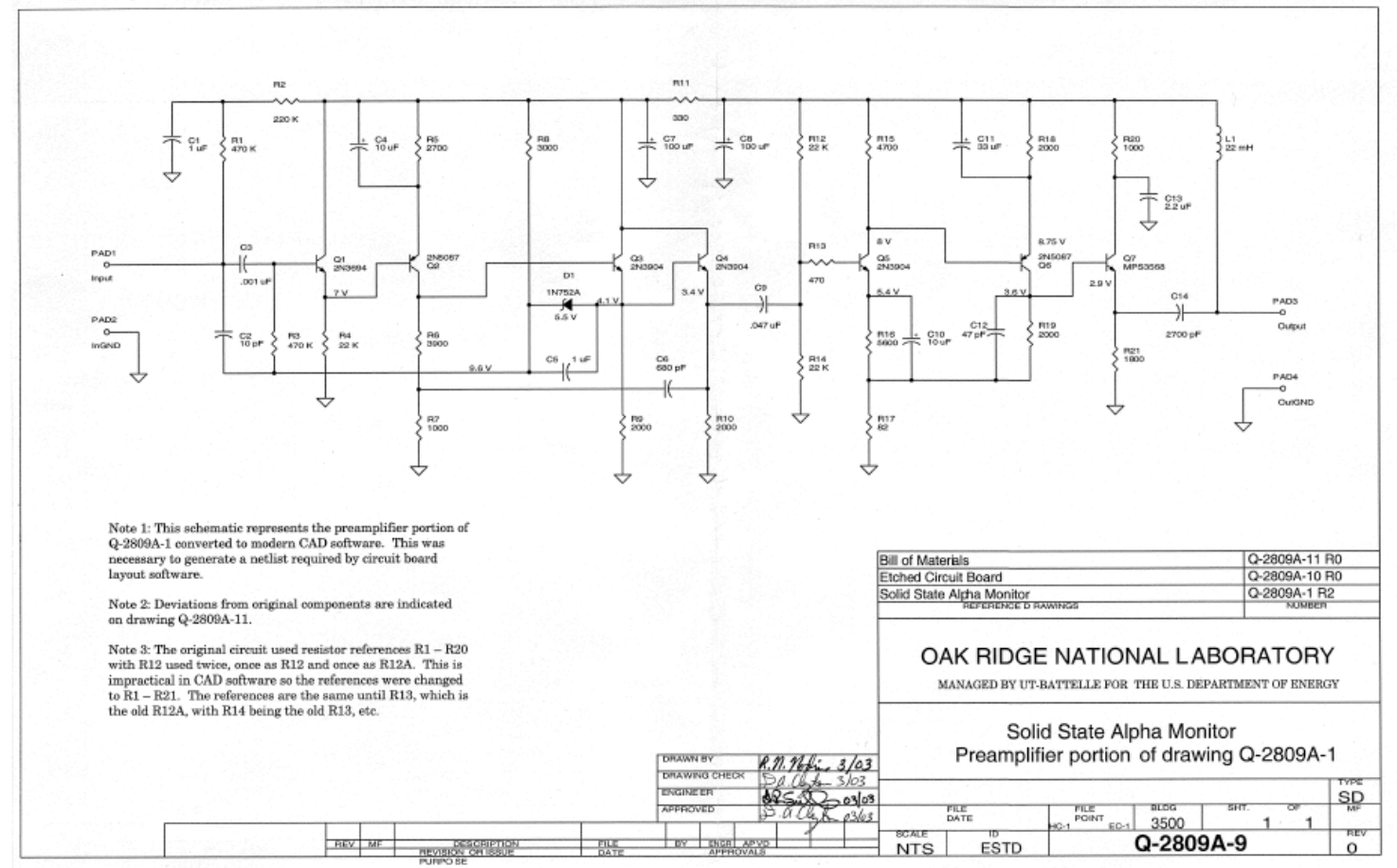

Figure 6. Q-2809A-9 \& 11 PreampSch \& Parts.

The CRMs were designed to use ion-implanted-silicon charged-particle detectors that are commonly referred to as silicon surface-barrier (SSB) detectors. SSB detectors are used for detecting and measuring the energy of charged particles. The chosen SSB detector is an AMETEK ORTEC CU-0140-100 that has an active area of $25 \mathrm{~mm}^{2}$. See Figure 7 below. 
Ultra Ion-Implanted-Silicon Detector made by Ametek cost Approx. \$1,000 Used in both Alpha and Neutron probes. Neutron probes uses detector with poly cap installed that comes with the detector from Ametek and the Alpha detector its removed.

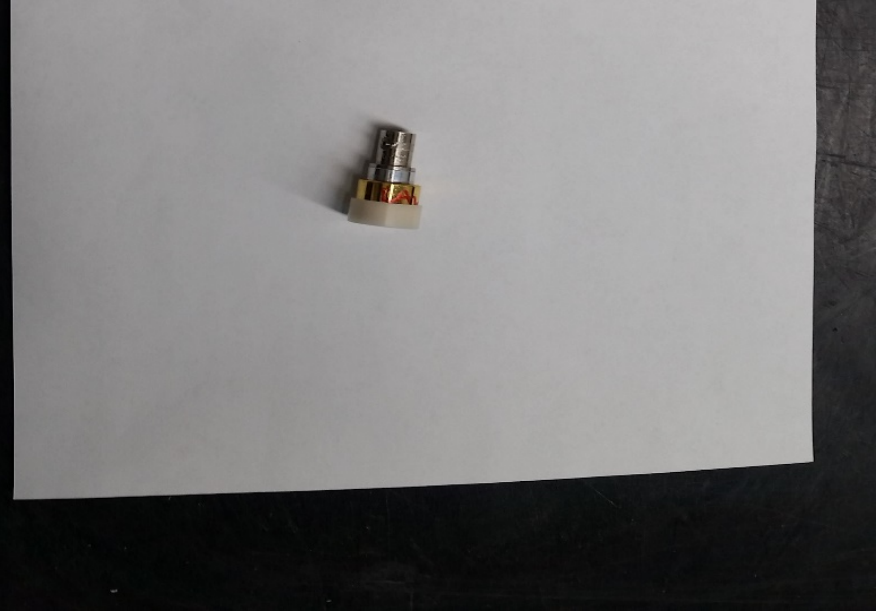

Figure 7. Silicon surface-barrier (SSB) detector.

Depending on the mechanical assembly the detector is installed within, it is able to measure alpha or neutron activity. The alpha probe assembly is designed to mount in line with the process piping on the equipment racks in the hot cell cubicles. The alpha probe uses two layers of very thin windows of aluminized (one side) Mylar film to protect the face of the detector from the process solution that flows through the probe assembly. The neutron probe is designed as a drop probe that can be either held in place by a master-slave manipulator or affixed to equipment. The detector of the neutron probe assembly is installed in an epoxy-encapsulated aluminum can with polyethylene neutron radiator and aluminum neutron cap. Both probe assemblies have a $6 \mathrm{ft}$ long RG62/U coaxial cable (coax) with single-pin LEMO quick-disconnect (QD) male plug. See Figure 8 below. 


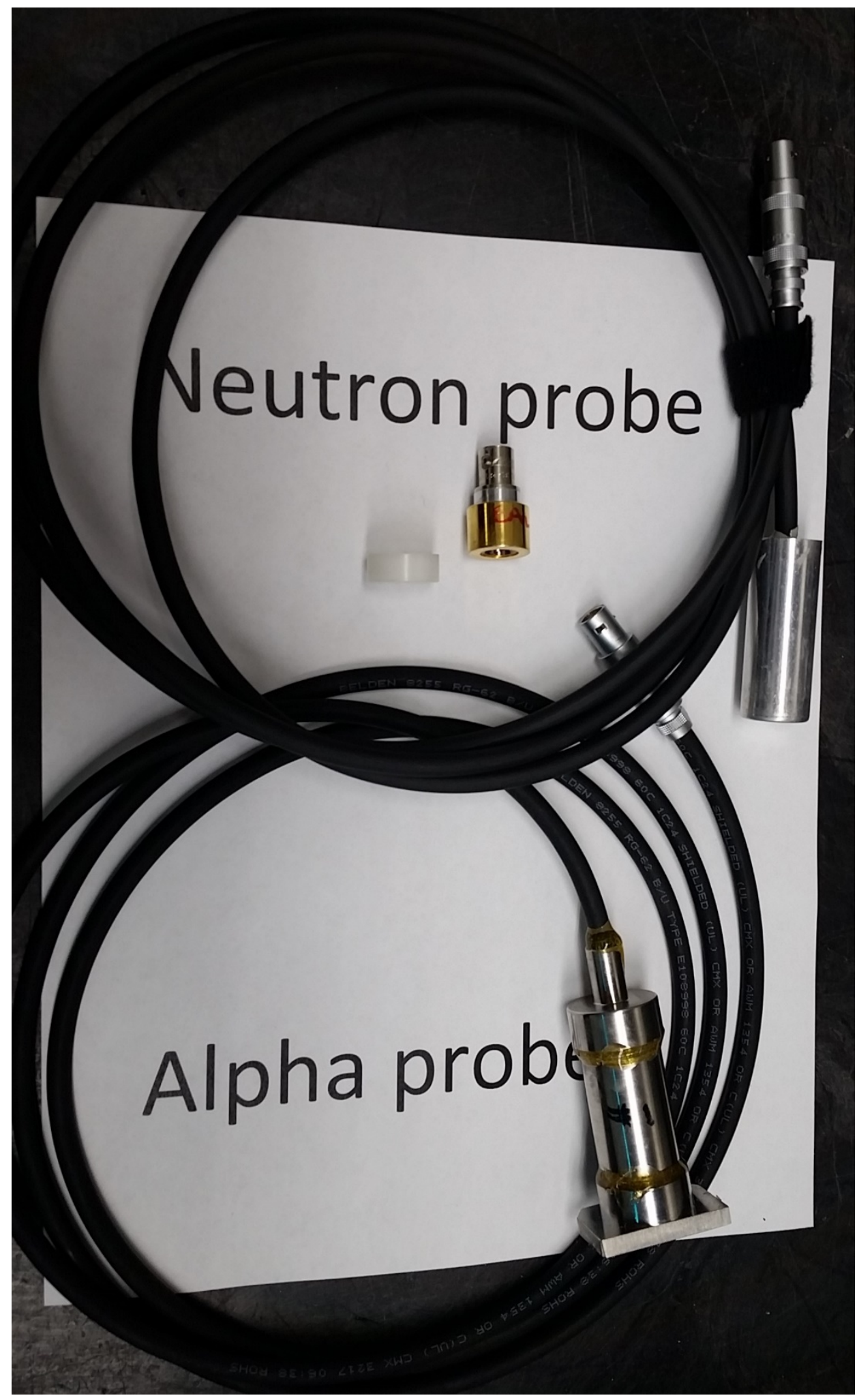

Figure 8. Neutron and alpha probe assemblies. 
The detector's LEMO QD plug is connected into a matching LEMO input jack on the Preamp Can. Because of the high radiation levels that occur during chemical processing campaigns, the useful operating life of the preamp cans and SSB detectors is only a few weeks.

\section{CUBICLE FRONT COAX CABLES}

In the cubicle, a coax extension cable with male LEMO QD plugs on each end is plugged into the output jack of the Preamp Can. The other end of the extension cable is plugged into a LEMO free socket cable collet, which is connected to one of the three RG59/U coax drop leads from the cubicle radiation disconnect mounted in the cubicle ceiling that are 6-7.5 ft long. See Coaxial Cable Assembly detail in Figure 9, N3E020995A259, Cubicle Interconnections Assembly. On top of the cubicle, the disconnect housing has three LEMO jacks. The LEMO jacks are used to connect the disconnect to a top-of-cubicle interconnection that is comprised of an Amphenol circular receptacle with three coax contacts wired to three $1 \mathrm{ft}$ long RG59/U coax cables with matching LEMO QD plugs. A mating Amphenol plug with three $50 \mathrm{ft}$ long RG59/U coaxes pulled inside conduit is plugged into the receptacle. See typical Cubicle Coaxial Cable Drop Leads wiring diagram in Figure 10, I3E020995A103, Interconnections Disconnects Typical Wiring Diagrams. The three coaxes run in conduit from the top of the cubicle, through the j-plug area in the Limited Access Area (LAA) into the false ceiling above the control room (Room 116). The conduit continues down through the ceiling and then terminates with BNC panel jacks on the front of the radiation service junction boxes located on the wall to the right of cubicle windows 4-7. The three BNC panel jacks are labeled A, B, and C.

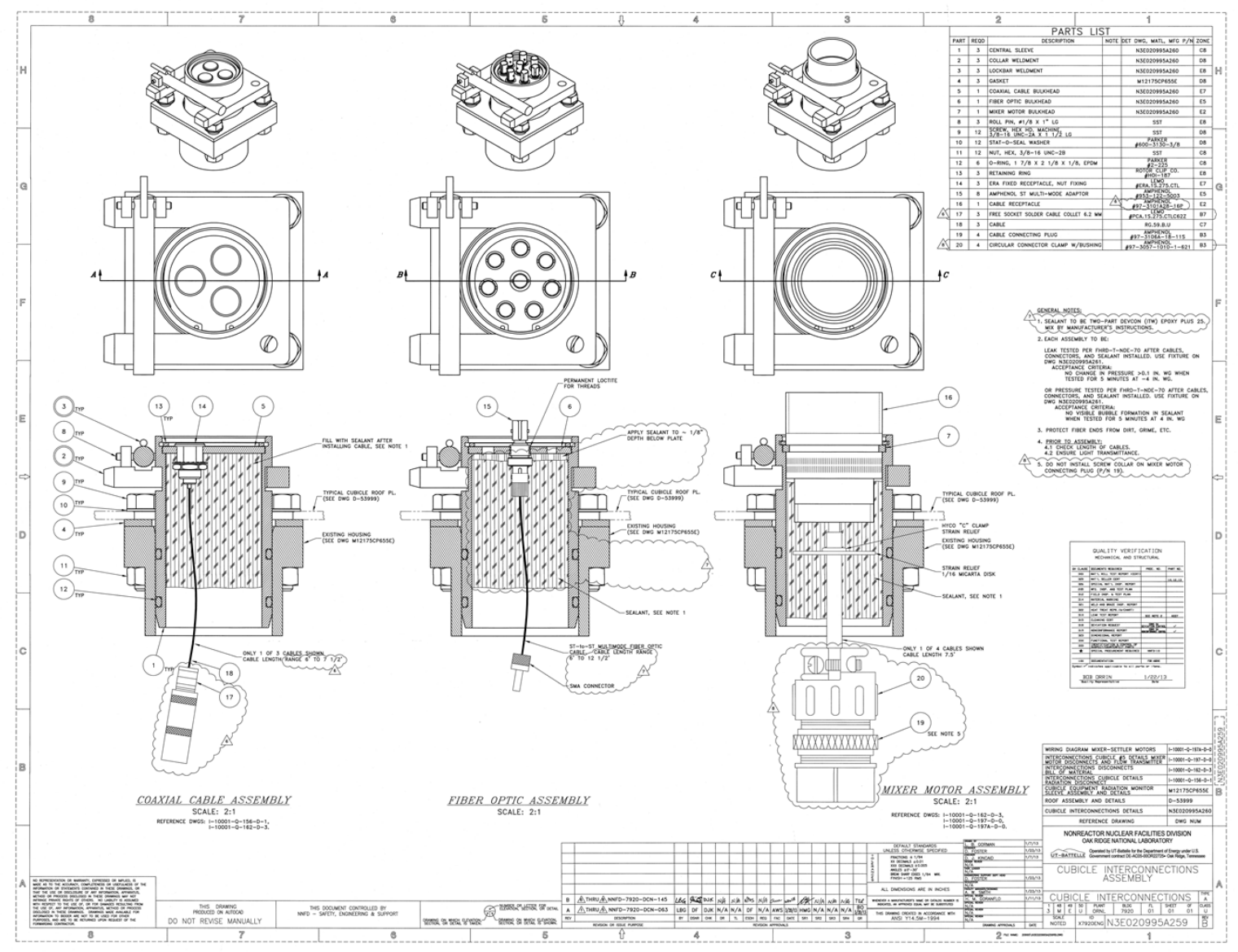

Figure 9. Cubicle Interconnections Assembly. 


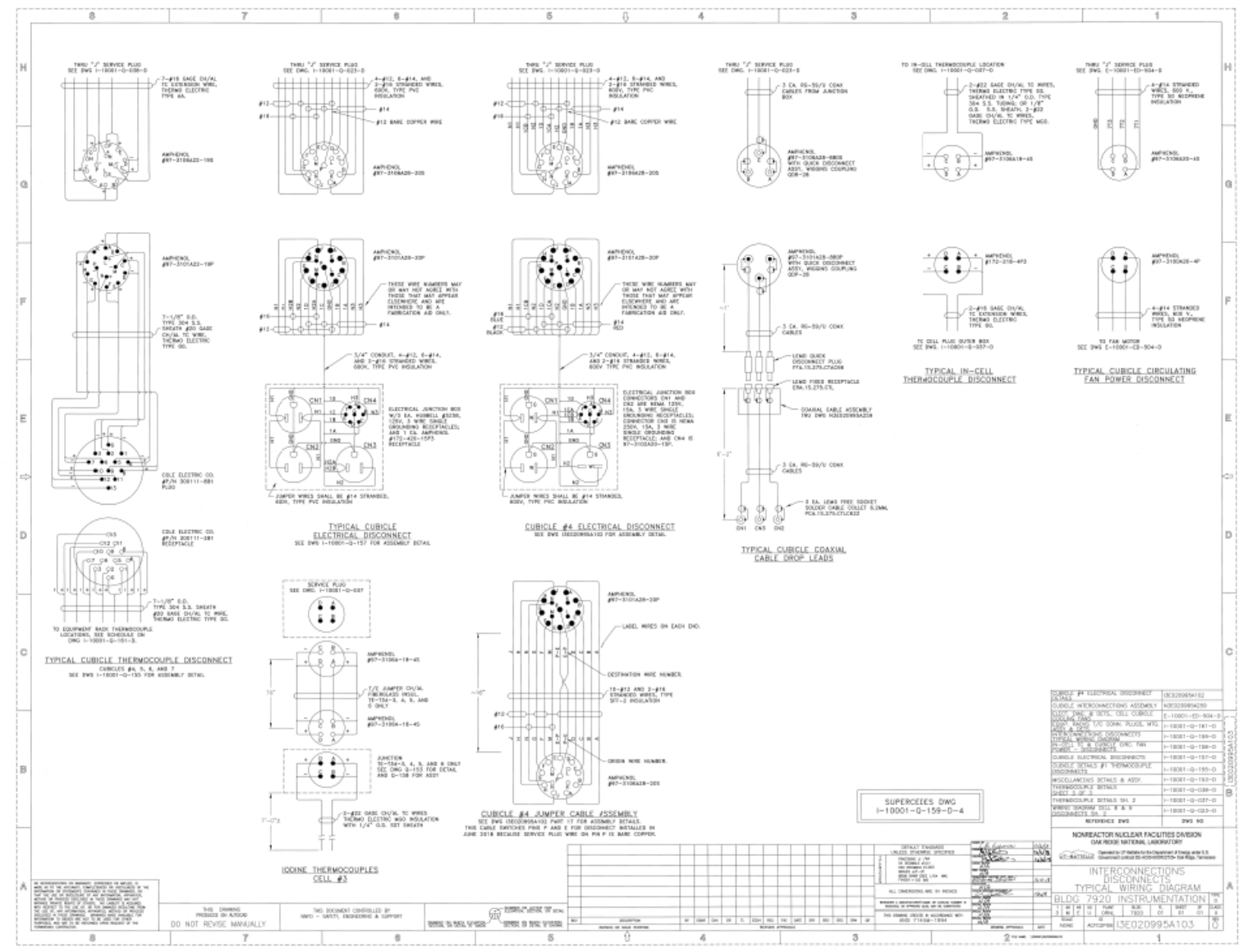

Figure 10. Interconnections Disconnects Typical Wiring Diagrams

In December 2014, before installing the LEMO drop leads, capacitance measurements were made to estimate the lengths of the coax cables with the original Miniature High Voltage (MHV) coax connector drop leads from the radiation service junction boxes at the face of the cubicles to the front drop leads inside the cubicles. A calibrated Fluke 87 digital multimeter using its capacitance function was employed to estimate the cable lengths. The nominal capacitance (conductor to shield) of RG59/U coax cable is $20.5 \mathrm{pF} / \mathrm{ft}$. One pico-Farad is $1 \times 10^{-12}$ Farads. The formula for estimating the length of coax cables is the measured cable capacitance divided by $20.5 \mathrm{pF} / \mathrm{ft}$. The calculated lengths of the cables are as follows:

\begin{tabular}{lll}
\hline Cubicle 4 & & \\
\hline BNC A & BNC B & BNC C \\
\hline $1,140 \mathrm{pF}, \sim 55.6 \mathrm{ft}$ & $1,150 \mathrm{pF}, \sim 56.0 \mathrm{ft}$ & $1,140 \mathrm{pF}, \sim 55.6 \mathrm{ft}$ \\
\hline Cubicle 5 & & \\
\hline $1,140 \mathrm{pF}, \sim 55.6 \mathrm{ft}$ & $1,180 \mathrm{pF}, \sim 57.6 \mathrm{ft}$ & $1,190 \mathrm{pF}, \sim 58.0 \mathrm{ft}$ \\
\hline Cubicle 6 & & \\
\hline $895 \mathrm{pF}, \sim 43.7 \mathrm{ft}$ & $1,178 \mathrm{pF}, \sim 52.6 .0 \mathrm{ft}$ & $1,104 \mathrm{pF}, \sim 53.9 \mathrm{ft}$ \\
\hline Cubicle 7 & & \\
\hline $1,170 \mathrm{pF}, \sim 57.1 \mathrm{ft}$ & $1,170 \mathrm{pF}, \sim 57.10 \mathrm{ft}$ & $1,170 \mathrm{pF}, \sim 57.1 \mathrm{ft}$ \\
\hline
\end{tabular}




\section{CUBICLE REAR CORNER COAX CABLES}

At the rear of cubicles 4 and 6, there are additional drop leads with BNC jacks on the ends of the cables. They are located at the southeast rear corner of the cubicles. Cubicles 4 and 6 have one set of three RG59/U cables each, whereas cubicle 5 has two sets of three RG59/U cables with LEMO free socket cable collets as previously noted. Cubicle 7 has a radiation service junction box located on the wall in the southeast rear corner. This junction box is similar to the Radiation Service Junction Box located on the wall to the right of the cubicle windows. The connectors on cubicle 7 junction box are nonserviceable because of prolonged exposure to the harsh environment inside the cubicle. Cubicles 4, 5, and 6 originally had the same junction boxes as cubicle 7 , but the boxes were removed and converted to drop leads. This is also true for the drop leads at the front of the cubicles.

Just as the drop leads in the front of the cubicles, the rear corner coax cables have top-of-cubicle interconnection drop leads above the cubicle ceiling. These cables are routed across the false ceiling of the control room (room 116) and come down in the rear of control panels MB-21 and MB-26. Control panel MB-26 also has three panel mounted Q-2809A CRMs that can use these cables. There are also two sets of three RG59/U jumper cables in the rear of MB-21 that are routed across the false ceiling of the control room to the front of cubicles 4 and 6. Using BNC union adapters in the control panels, these cables are used as jumper cables to connect the cubicle rear corner cables to the portable radiation cabinet ratemeters at the cubicle face. At this time, the drawing that contains these cables, their details, and how they are routed is missing.

Since there is no known drawing that contains the details for these RG59/U cables, a calibrated Fluke 87 digital multimeter using its capacitance function was employed to estimate the cable lengths. The nominal capacitance (conductor to shield) of RG59/U coax cable is $20.5 \mathrm{pF} / \mathrm{ft}$. One pico-Farad is $1 \times 10^{-12}$ Farads. The formula for estimating the length of coax cables is the measured cable capacitance divided by the nominal capacitance specification of RG59/U coax $(20.5 \mathrm{pF} / \mathrm{ft})$. The calculated lengths of the cables are as follows:

\begin{tabular}{lll}
\hline Cubicle $\mathbf{4}$ & & \\
\hline Southeast corner drop leads & Jumper leads to Cubicle 4 face & Drop + jumper leads \\
\hline 2,580 pF, $\sim 121 \mathrm{ft}$ & $1,110 \mathrm{pF}, \sim 54 \mathrm{ft}$ & $3,690 \mathrm{pF}, \sim 180 \mathrm{ft}$ \\
\hline Cubicle $\mathbf{5}$ & & \\
\hline Southeast corner drop leads & 2nd set southeast corner drop leads & \\
\hline 2,290 pF, $\sim 112 \mathrm{ft}$ & $2,290 \mathrm{pF}, \sim 112 \mathrm{ft}$ & \\
\hline Cubicle $\mathbf{6}$ & & \\
\hline Southeast corner drop leads & Jumper leads to Cubicle 6 face & Drop + jumper leads \\
\hline 3,260 pF, $\sim 159 \mathrm{ft}$ & $1,410 \mathrm{pF}, \sim 69 \mathrm{ft}$ & $4,670 \mathrm{pF}, \sim 228 \mathrm{ft}$ \\
\hline Cubicle 7 & & \\
\hline $\begin{array}{l}\text { Southeast corner radiation service } \\
\text { junction box }\end{array}$ & & \\
\hline $\begin{array}{l}\text { 2,580 } \mathrm{pF}, \sim 121-126 \mathrm{ft}(\text { due to } \\
\text { corrosion, readings are suspect) }\end{array}$ & & \\
\hline
\end{tabular}




\section{WIRING LIMITATIONS}

Cubicles 4-7 were designed primarily to perform chemical processing using mostly mechanical equipment, air and electrically operated pumps, motors, and furnaces. Other than thermocouple connections and the coax drop leads noted above, the cubicles do not have any instrument-quality wiring, such as shielded multiconductor cables. There is a junction box with three $120 \mathrm{~V}$ NEMA receptacles (one remotely switched) and a single seven-pin Amphenol receptacle. The Amphenol provides power to electric motors or other simple electric equipment. However, these connections are dedicated and are not available for use. The lack of instrument wiring in the cubicles eliminates single box solutions from manufacturers such as Canberra, Eberline, and Ludlum from being considered. All off-the-shelf single box solutions investigated require multiconductor cables between the detector and meter readout in the control room. The design and installation cost for removing the old cables and pulling new suitable instrument cables between the cubicle and the control room would be prohibitive.

\section{TOUCH SCREEN PAPERLESS RECORDER}

The existing two-pen paper recorder was replaced with a Yokogawa GX20 paperless recorder with 10 analog inputs. The GX20 paperless recorder displays real-time measured data on a $12.1 \mathrm{in}$. touch screen and saves data on an external storage medium (SD card). The GX20 has 1.2 GB of internal memory, making prolonged record and preservation possible. The GX20 is connected to the ORNL's internal network device with IP name redcgx20.ornl.gov and IP number 10.102.130.XXX. Touch screen operations including swipe and pinch-to-zoom are possible. Under recording, past trends can be seamlessly displayed on screen. Moreover, the measurement data of the time specified on the calendar screen can be searched and displayed. Various equipped functions, such as freehand message, PDF/Excel output of report files, scale movement of trend display, and buzzer sound, are included. It is hooked up to the network via Ethernet, which enables remote monitoring by computer of its internal Web site as well as to transfer files by using FTP or direct output to a network printer. A logarithmic (Log) voltage or Log linear input (Input that is linear on a logarithmic scale) can be applied to the GX, and then the GX's Log scale (logarithmic scale) is used to display and record the physical value. Two examples of these recordings can be seen in Figure 11 and Figure 12 below. 


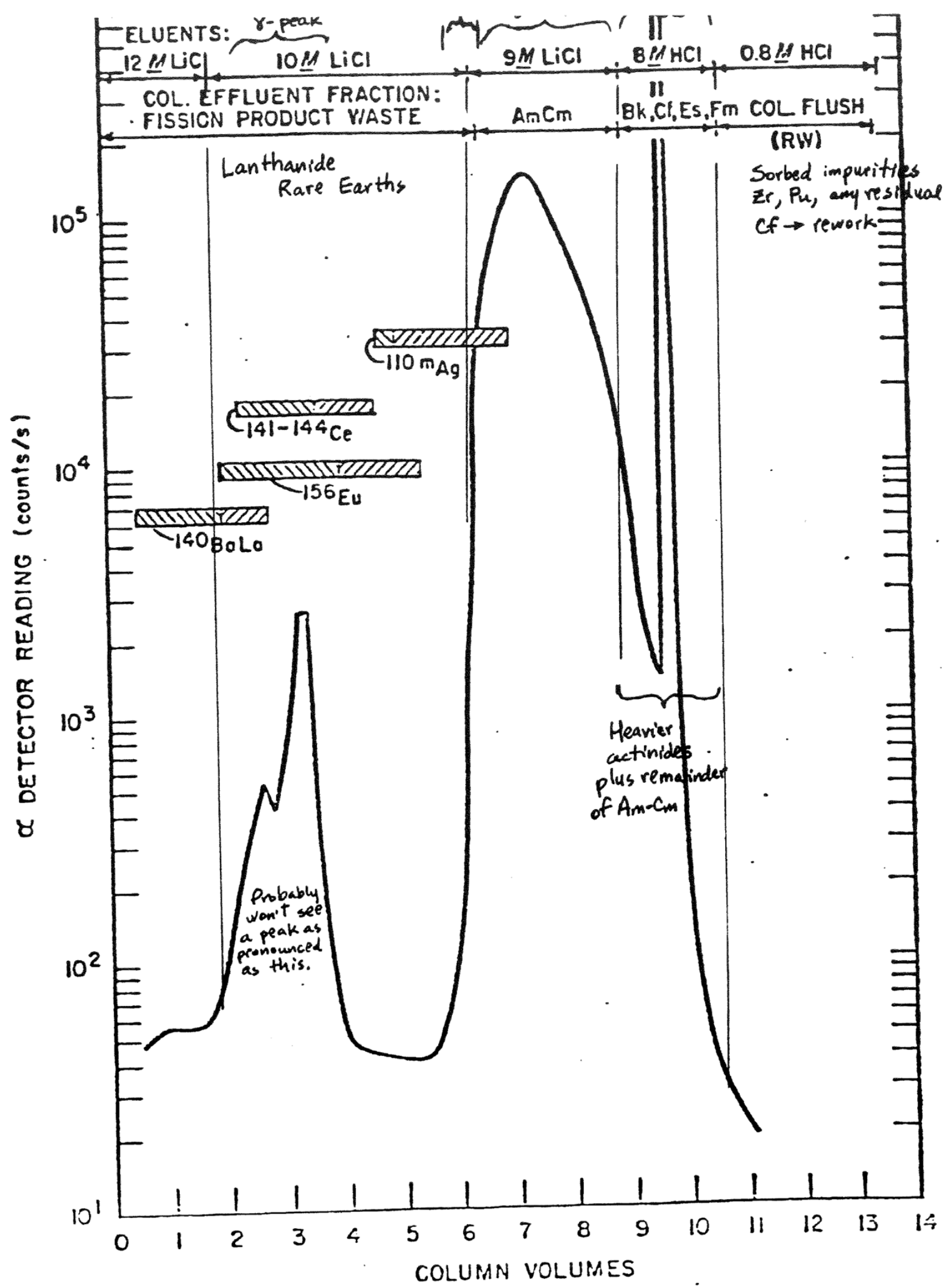

Figure 11. Typical run. 
UHNL UAg OU-ICIUJAT

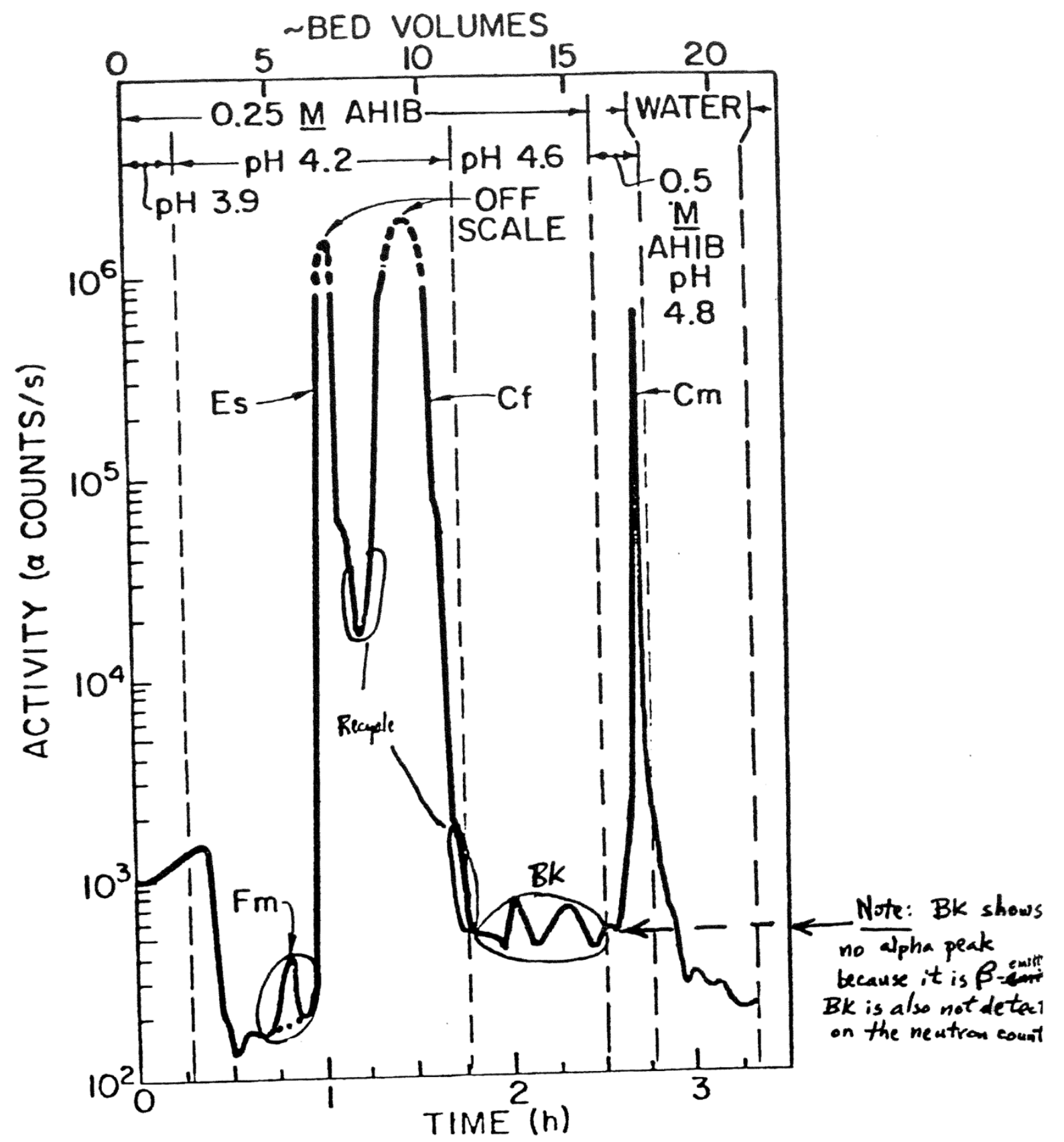

RESPONSE FROM FLOW-THROUGH

$a$-DETECTOR DURING ELUTION OF RUN $52-C X-2$

\section{"Typical" BUT COLUMN RUN}

Figure 12. Typical BUT column run. 


\section{APPENDIX B. PREAMPLIFIER TEST PROCEDURE, 09-14-2021, REV.A}

\section{TEST EQUIPMENT NEEDED}

1. Operating CRM module

2. Waveform generator (Keysight $33500 \mathrm{~B}$ or equivalent)

3. Oscilloscope

4. Voltmeter

5. Test pulser input box

6. LEMO-BNC adapter

7. BNC Tee

\section{PROCEDURE}

Note, the preamplifier needs to be soldered to the can top tabs ready to be put into the can to properly test due to shielding.

1. Connect the preamp under test (PUT) as shown below.

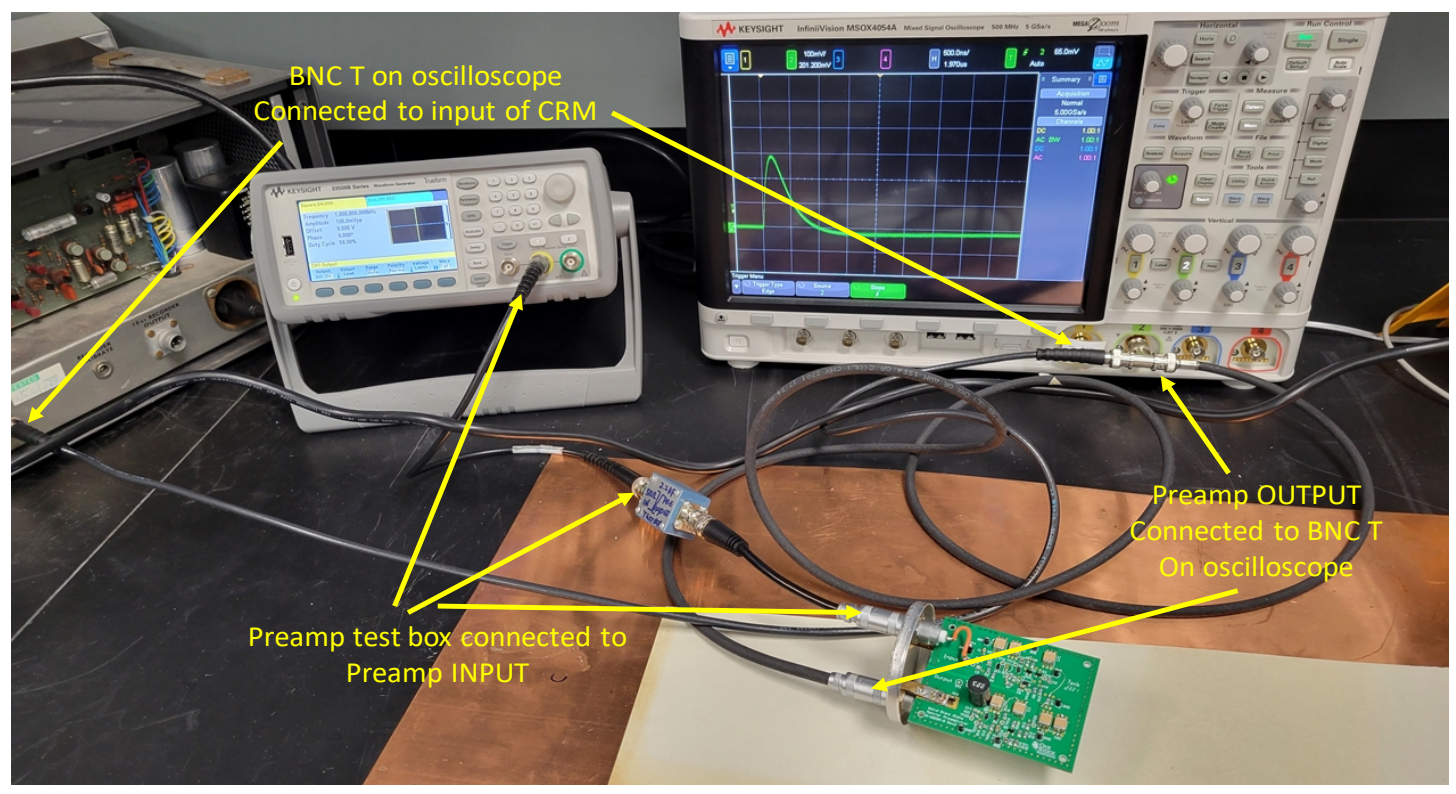

2. Turn on the CRM.

3. Check the following voltages against the Table A voltages.
a. VDD
b. VDD-filt
c. VDD-det
d. TP26
e. TP19
f. TP17
g. TP20

4. These should be within $0.5 \mathrm{~V}$.

5. Setup for the generator

h. Waveform type - square wave 
i. Leading edge risetime- $-10 \mathrm{~ns}$

j. Rate $-1 \mathrm{kHz}$

k. Amplitude- $100 \mathrm{mV}$

1. Time/div-500 $\mathrm{nS}$

6. Set the oscilloscope channel 1 as follows

m. Sensitivity- $100 \mathrm{mV}$

n. Coupling-AC

7. Trigger the oscilloscope on channel 1.

8. Set the trigger to respond to + leading edges.

9. Enable the pulser and trigger above noise until ONLY positive-going signals are showing. 10. Signal should appear as shown.

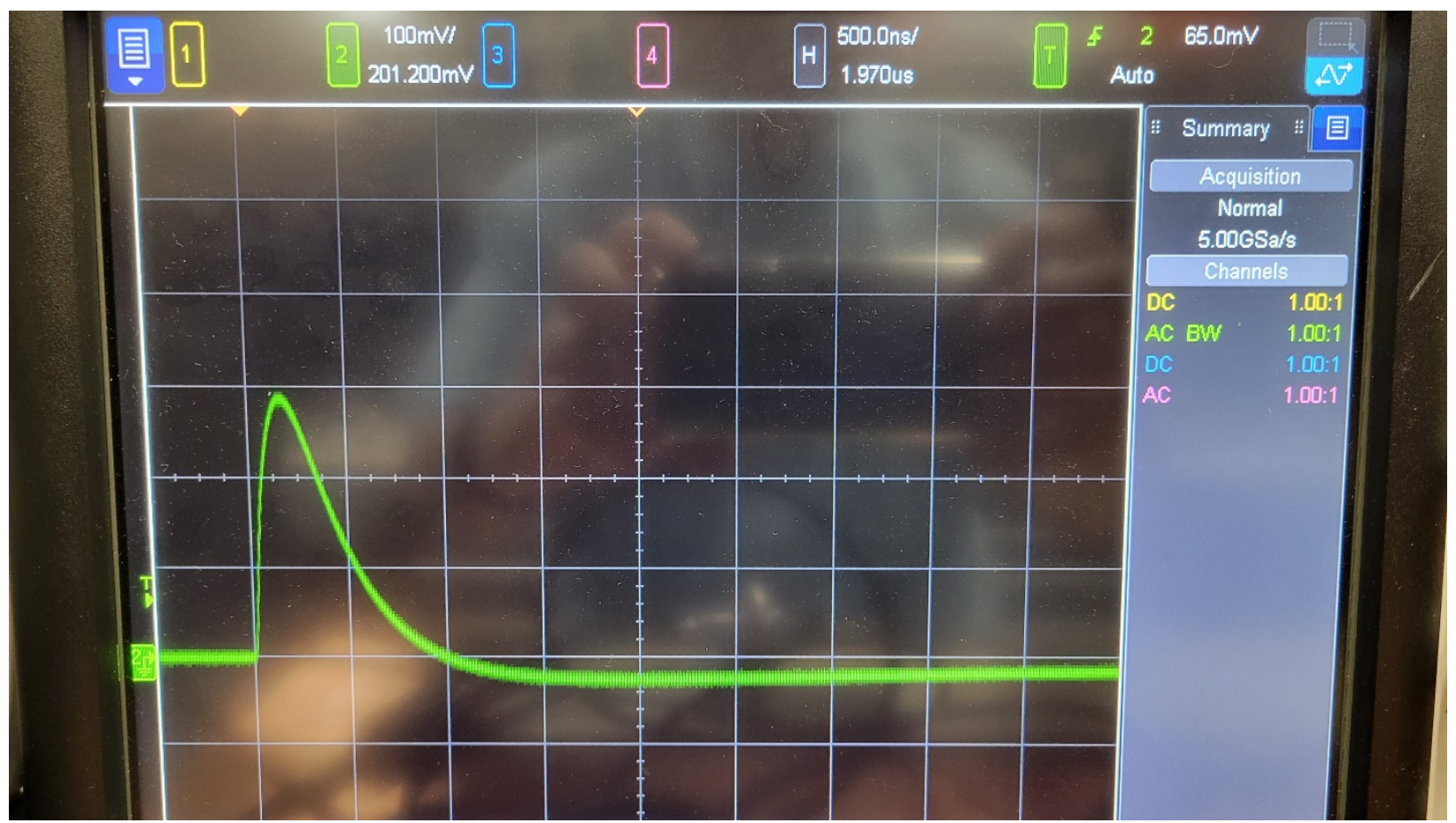

After these tests, disconnect the test box from the preamp input and check the noise. The channel sensitivity will need to be changed to approximately $5 \mathrm{mV} /$ div. The noise should appear as below with a peak-peak value of approximately $5 \mathrm{mV}$. 


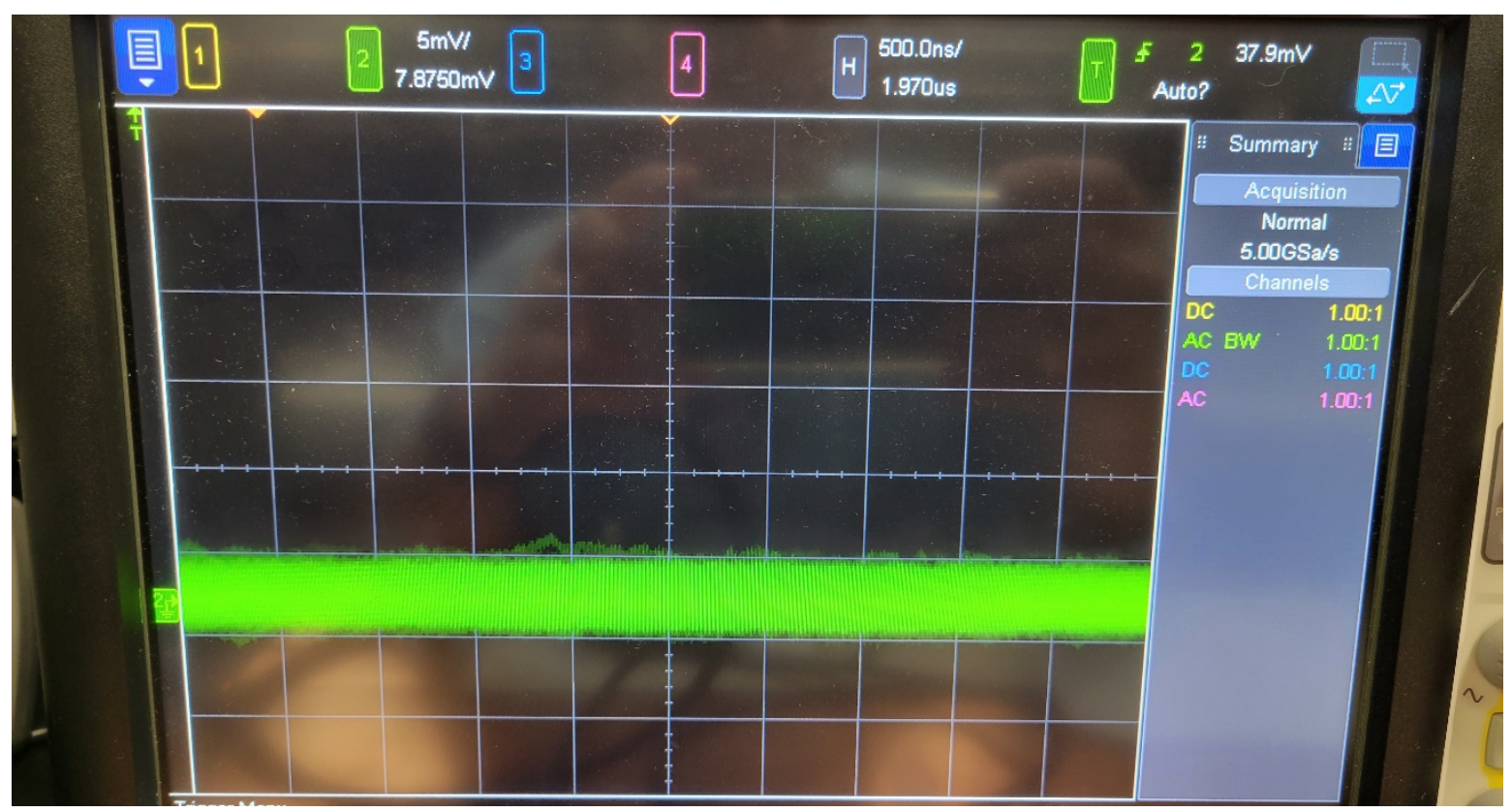

Table A. Test point approximate voltages.

\begin{tabular}{lc}
\hline \multicolumn{1}{c}{ Test } & Voltage \\
\hline VDD & 14 \\
VDD-filt & 13.6 \\
VDD-det & 11.5 \\
TP26 & 14 \\
TP19 & 4.3 \\
TP17 & 8.5 \\
TP20 & 11 \\
\hline
\end{tabular}




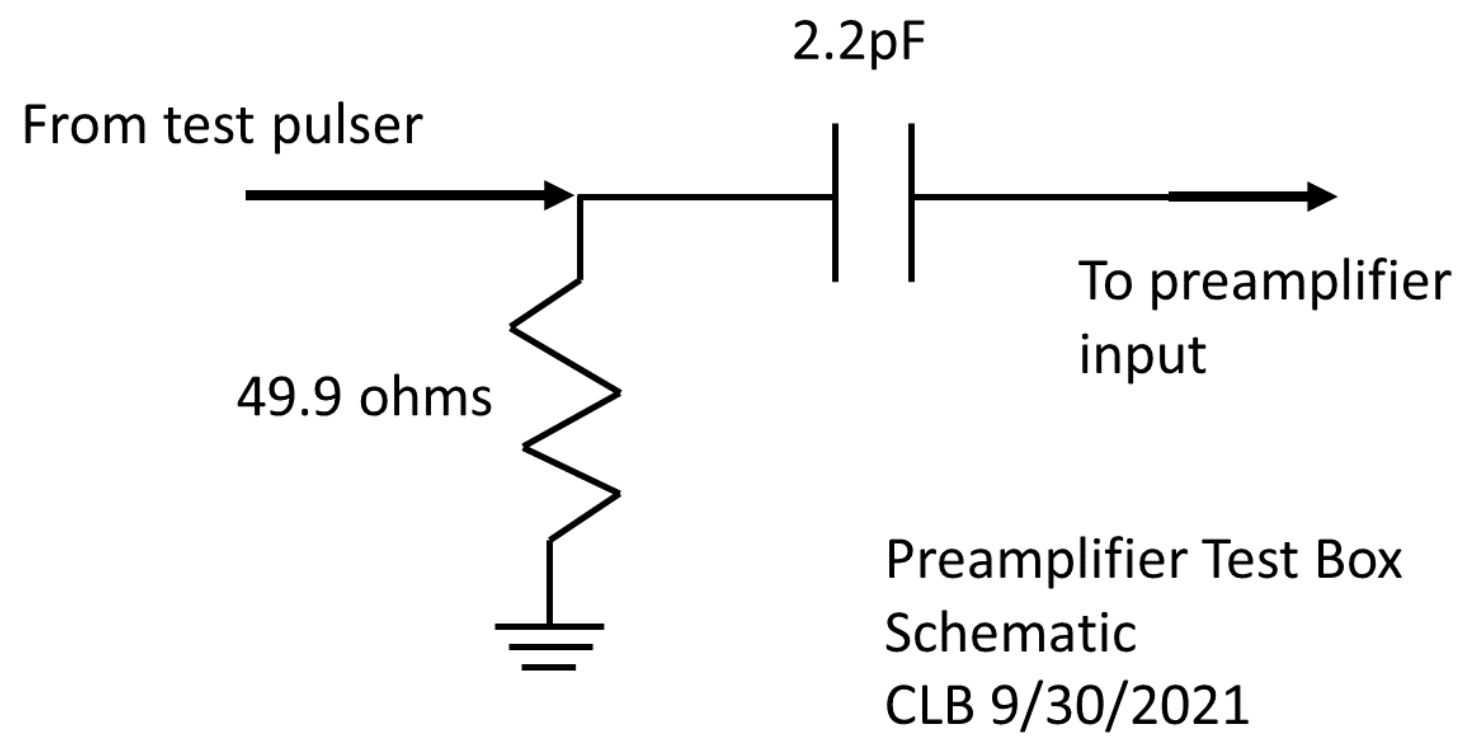

NOTES

1. The preamplifier schematic is attached.

2. Test data from the Rev. 4 prototype is also included for troubleshooting. 


\section{APPENDIX C. CRM TEST PROCEDURE, 09-14-2021, REV. A}

\section{TEST EQUIPMENT NEEDED}

1. Waveform generator (Keysight $33500 \mathrm{~B}$ or equivalent).

2. Oscilloscope

3. Voltmeter

4. CRM test box

\section{CALIBRATION PROCEDURE}

1. Configure the waveform generator as shown below.

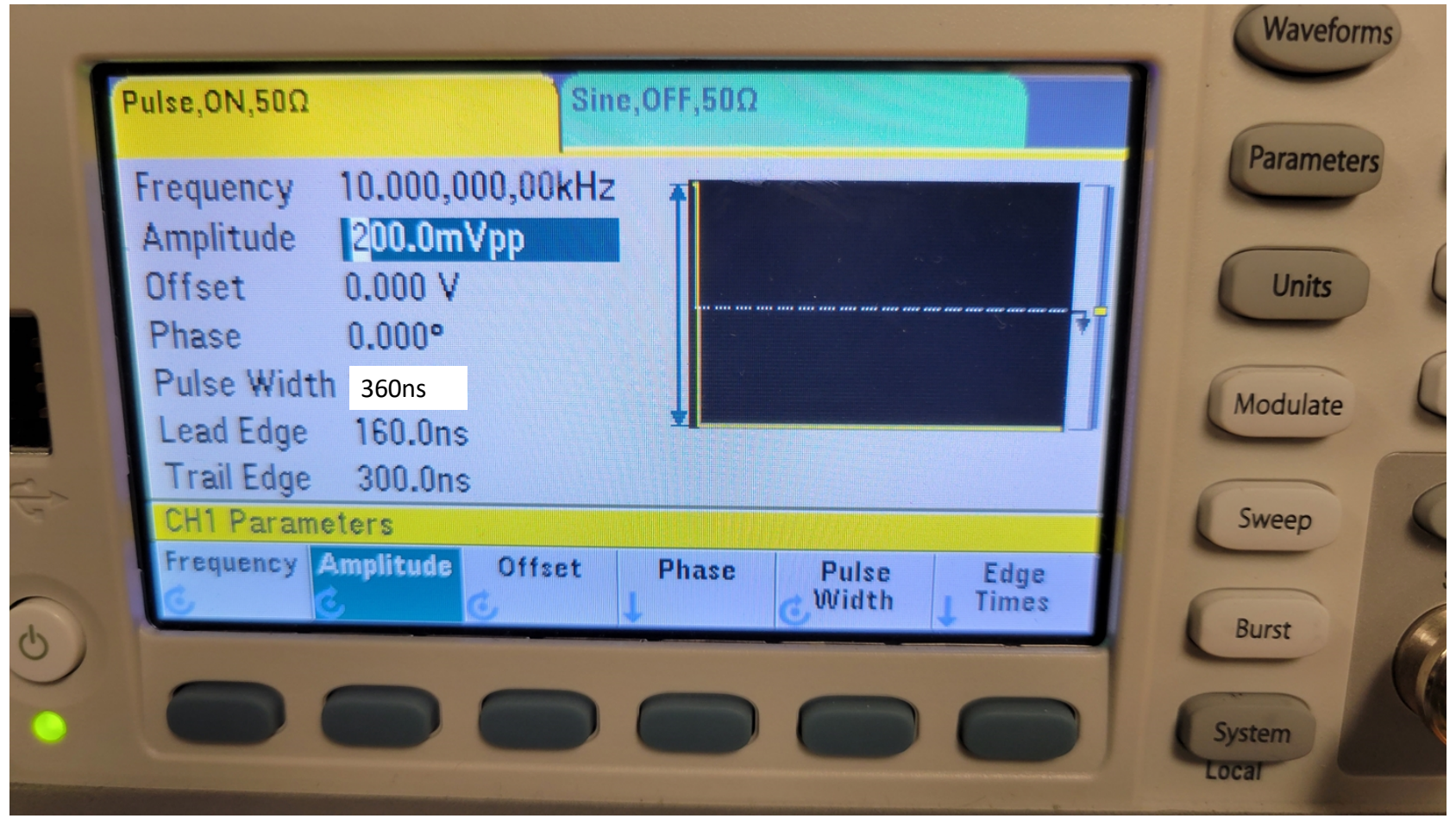

This will create a triangle-shaped pulse that emulates the preamp output that should look like the waveform below at the INPUT to the CRM. 


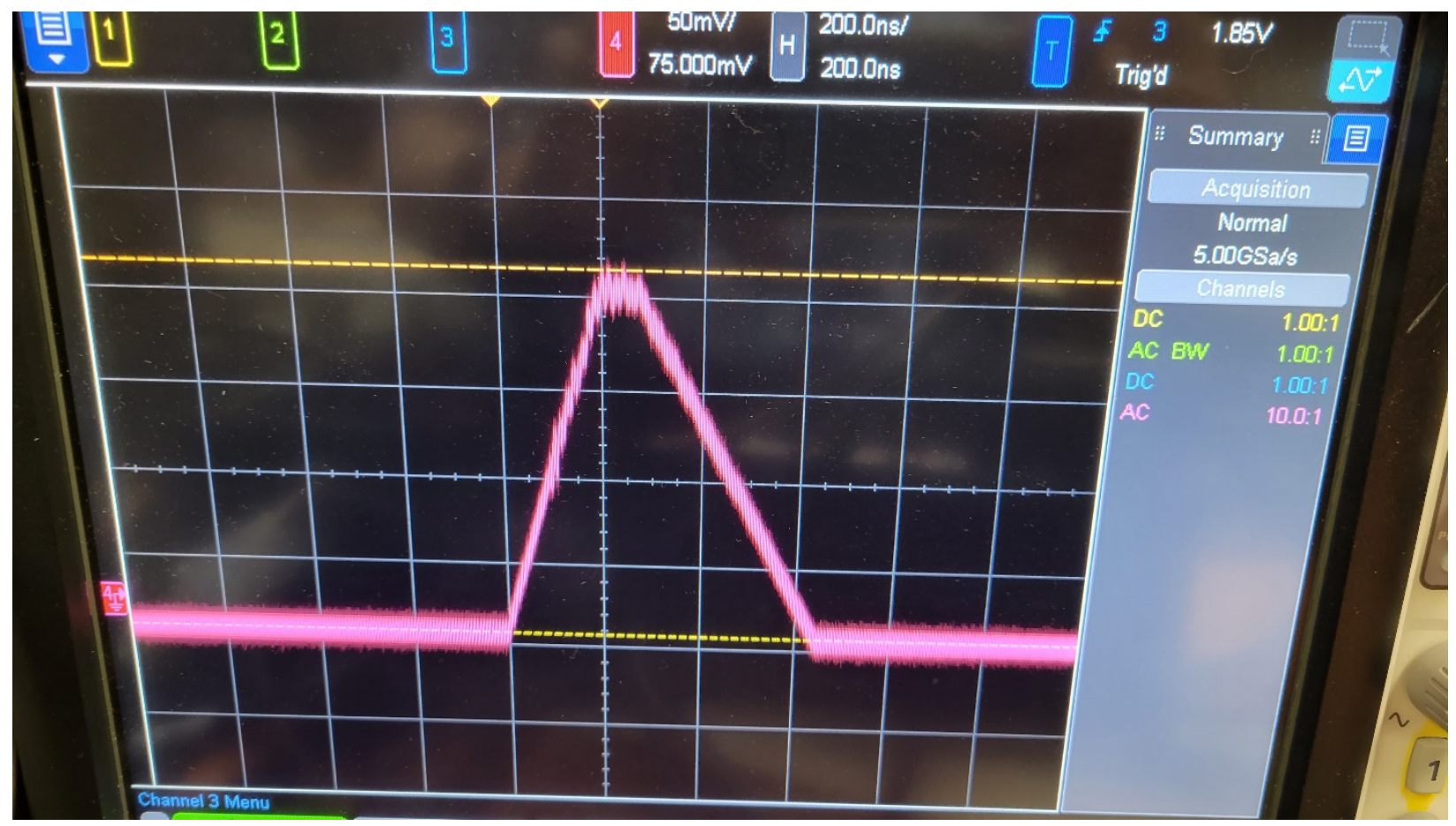

2. Test the following voltages on the CRM board:
a. $\mathrm{P} 2$, pin $1=+15 \mathrm{~V}$
b. $P 2$, pin $3=-15 \mathrm{~V}$
c. $\mathrm{TP} 7=+15 \mathrm{~V}$
d. $\mathrm{TP} 16=-0.6 \mathrm{~V}$
e. $\mathrm{TP} 6=4.9 \mathrm{~V}$
f. $\mathrm{TP} 20=-6.4 \mathrm{~V}$
g. $\mathrm{TP} 22=-5.8 \mathrm{~V}$
h. $\mathrm{TP} 19=-14.8 \mathrm{~V}$

3. Adjust R22 fully clockwise.

4. Set the front-panel knobs as follows
i. INTEGRATE TIME-LONG
j. RANGE-X10

5. Set the frequency on the waveform generator to $10 \mathrm{~Hz}$.

6. Place a voltameter across the RATE MEASUREMENT terminals, positive on top, negative on bottom.

7. Enable the waveform generator output.

8. Adjust R63 until the voltage settles to $1.0 \mathrm{~V}$.

9. Set $\mathrm{RANGE}=\mathrm{X} 100$.

10. Adjust R62 until the voltage settles to $1.0 \mathrm{~V}$.

11. Set $\mathrm{RANGE}=\mathrm{X} 1 \mathrm{~K}$.

12. Adjust R60 until the voltage settles to $1.0 \mathrm{~V}$.

13. Switch INTEGRATE TIME to MED.

14. Voltmeter should jump and return to previous value.

15. Switch INTEGRATE TIME to SHORT. 
16. Voltmeter should jump and return to previous value.

17. Return INTEGRATE TIME switch to LONG.

18. Set $\mathrm{RANGE}=\mathrm{X} 10 \mathrm{~K}$.

19. Adjust R59 until the voltage settles to $1.0 \mathrm{~V}$.

20. Set RANGE $=\mathrm{X} 100 \mathrm{~K}$.

21. Adjust R57 until the voltage settles to $1.0 \mathrm{~V}$.

22. Probe RECORDER OUTPUT pins 2 and $3(+$ and - ) on the rear of the module.

23. Set RANGE $=\mathrm{X} 1 \mathrm{~K}$.

24. Adjust R41 until the voltage settles to $10 \mathrm{mV}$.

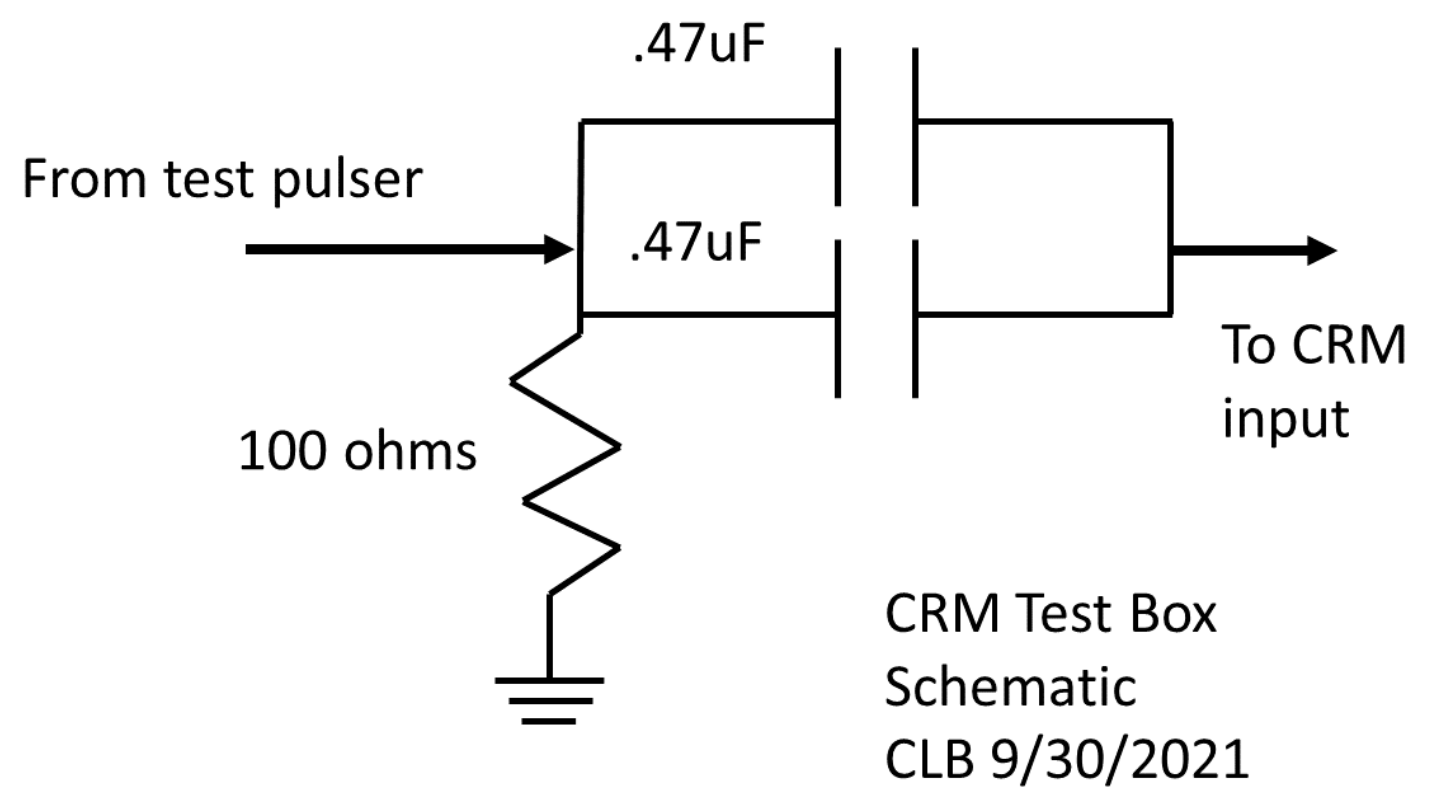




\section{APPENDIX D. PREAMPLIFIER SCHEMATIC AND LAYOUT}

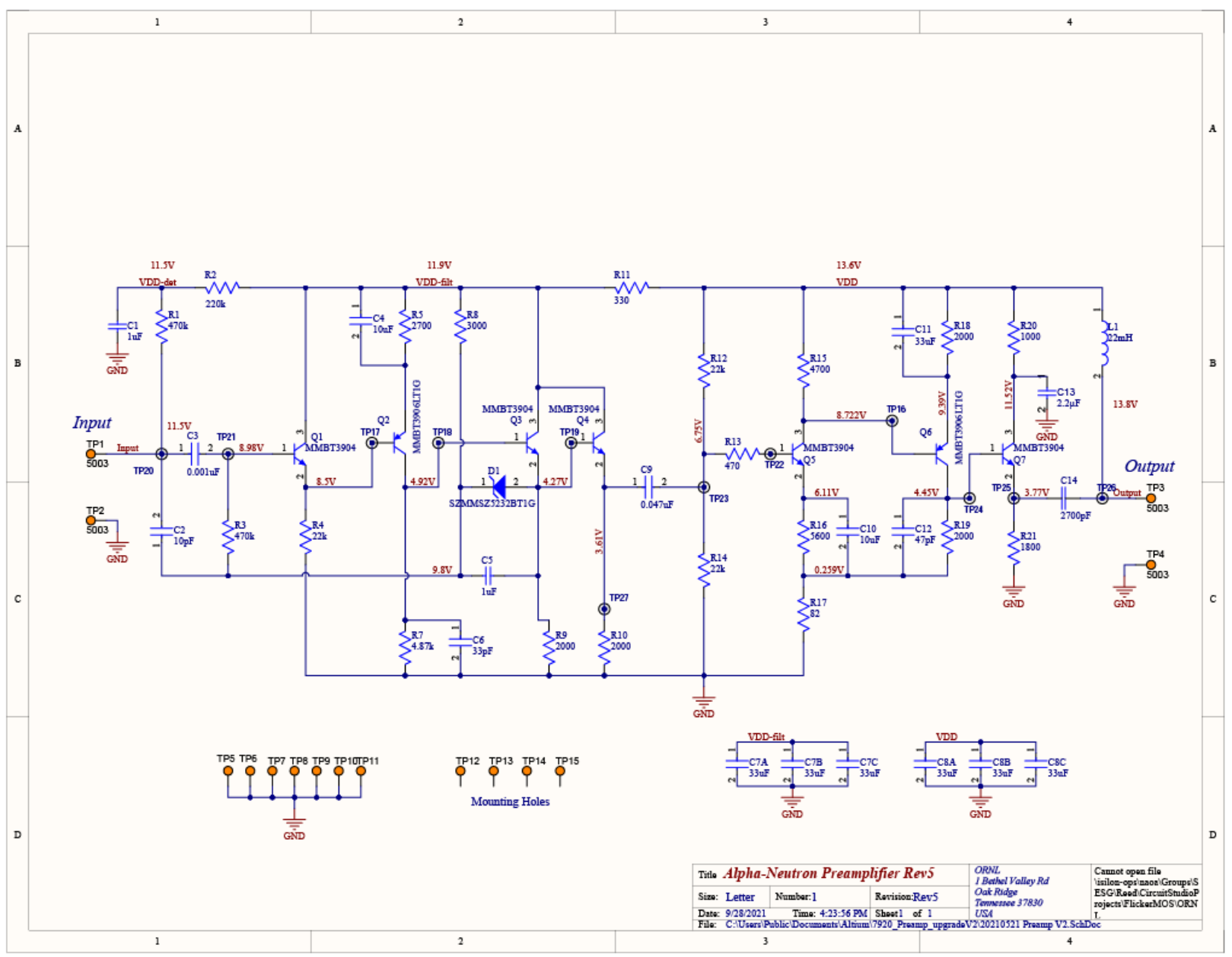




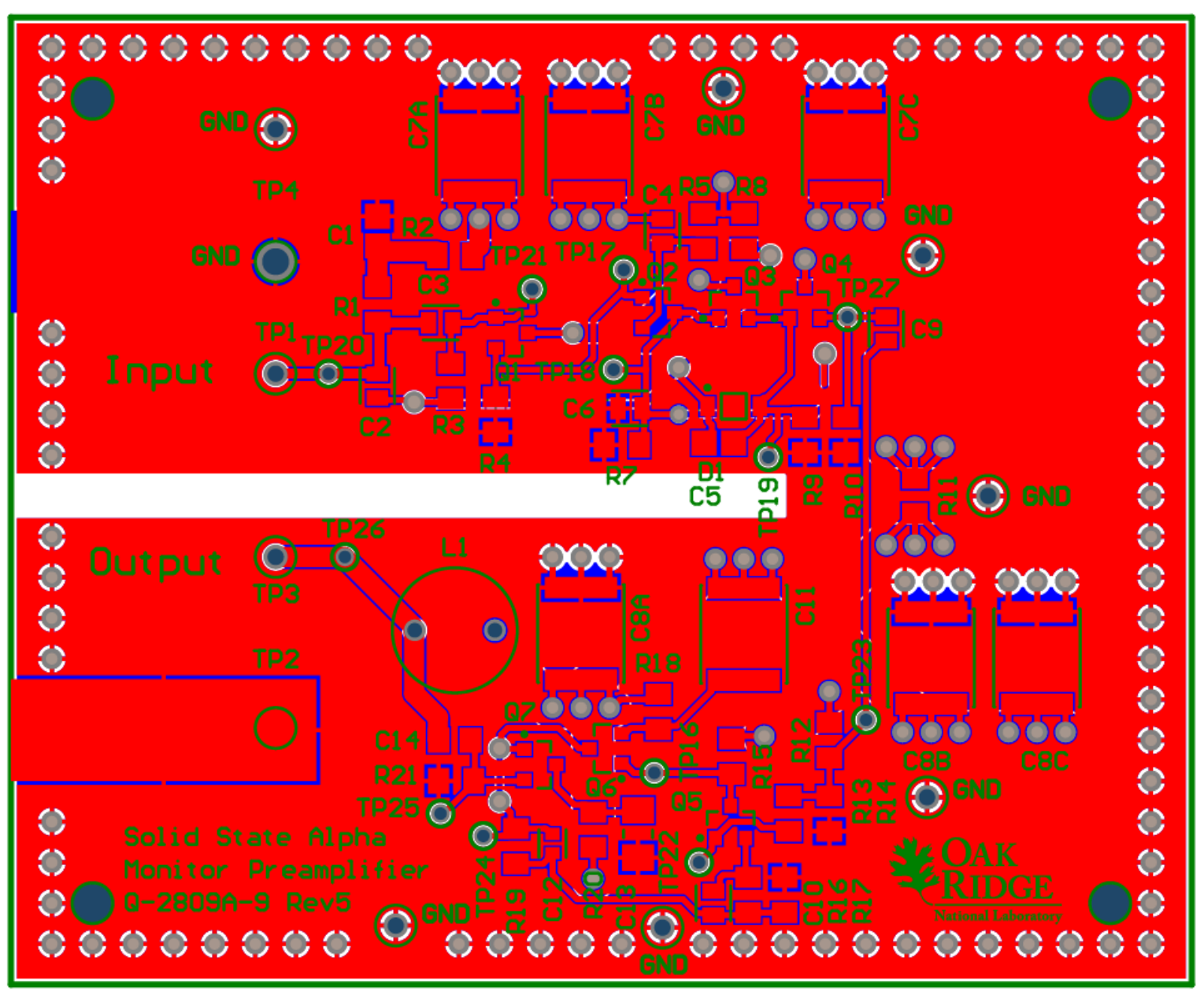




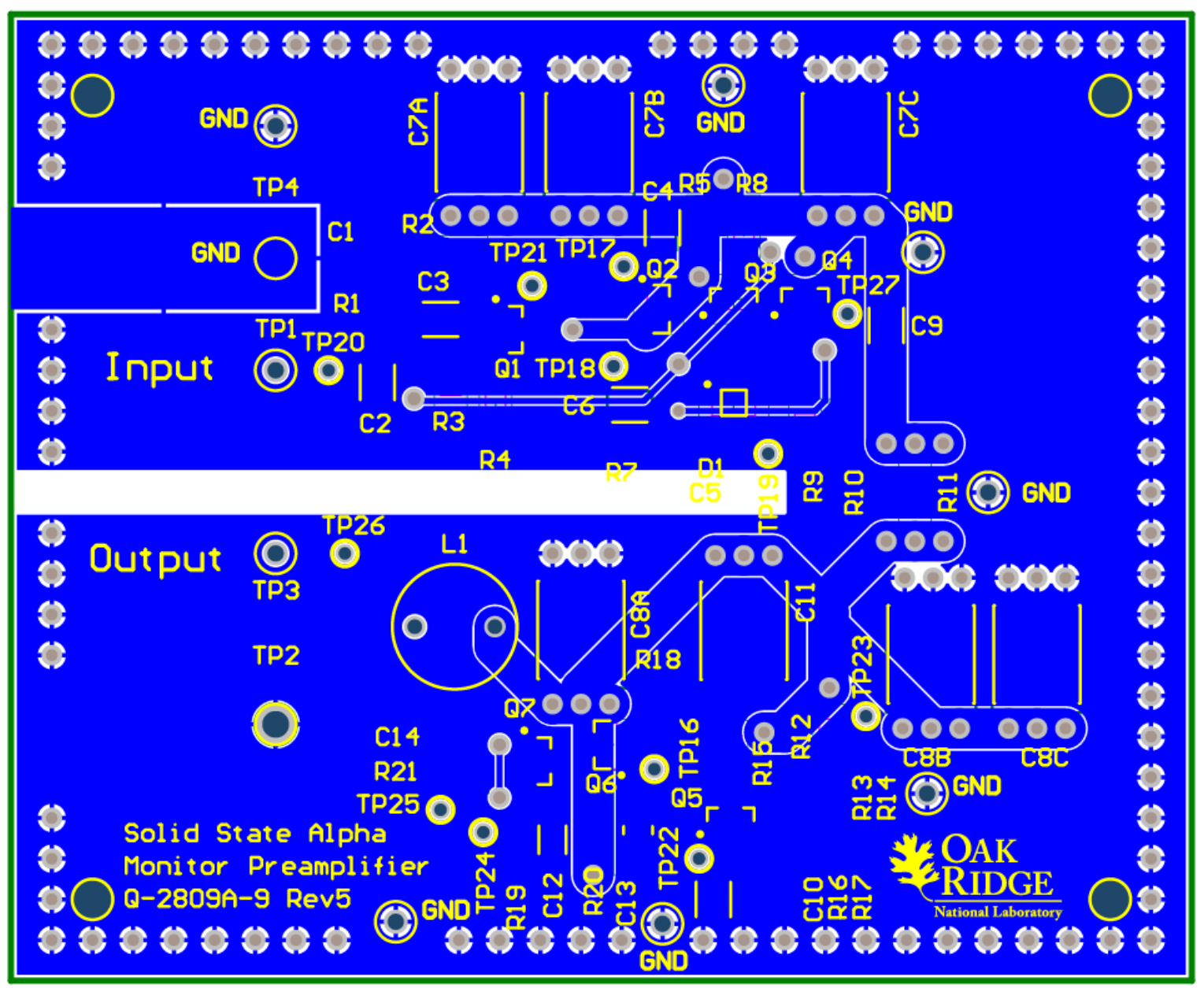




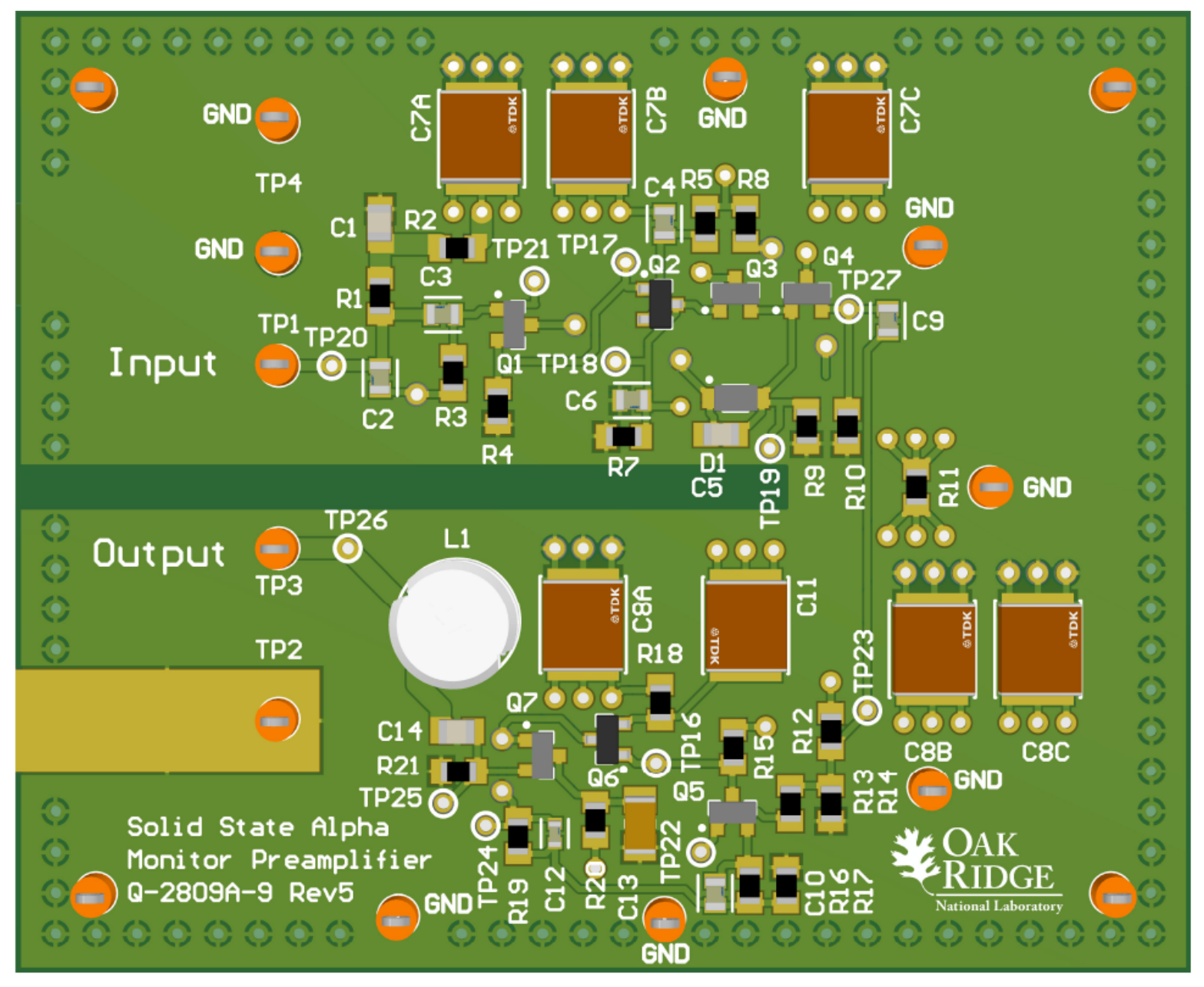




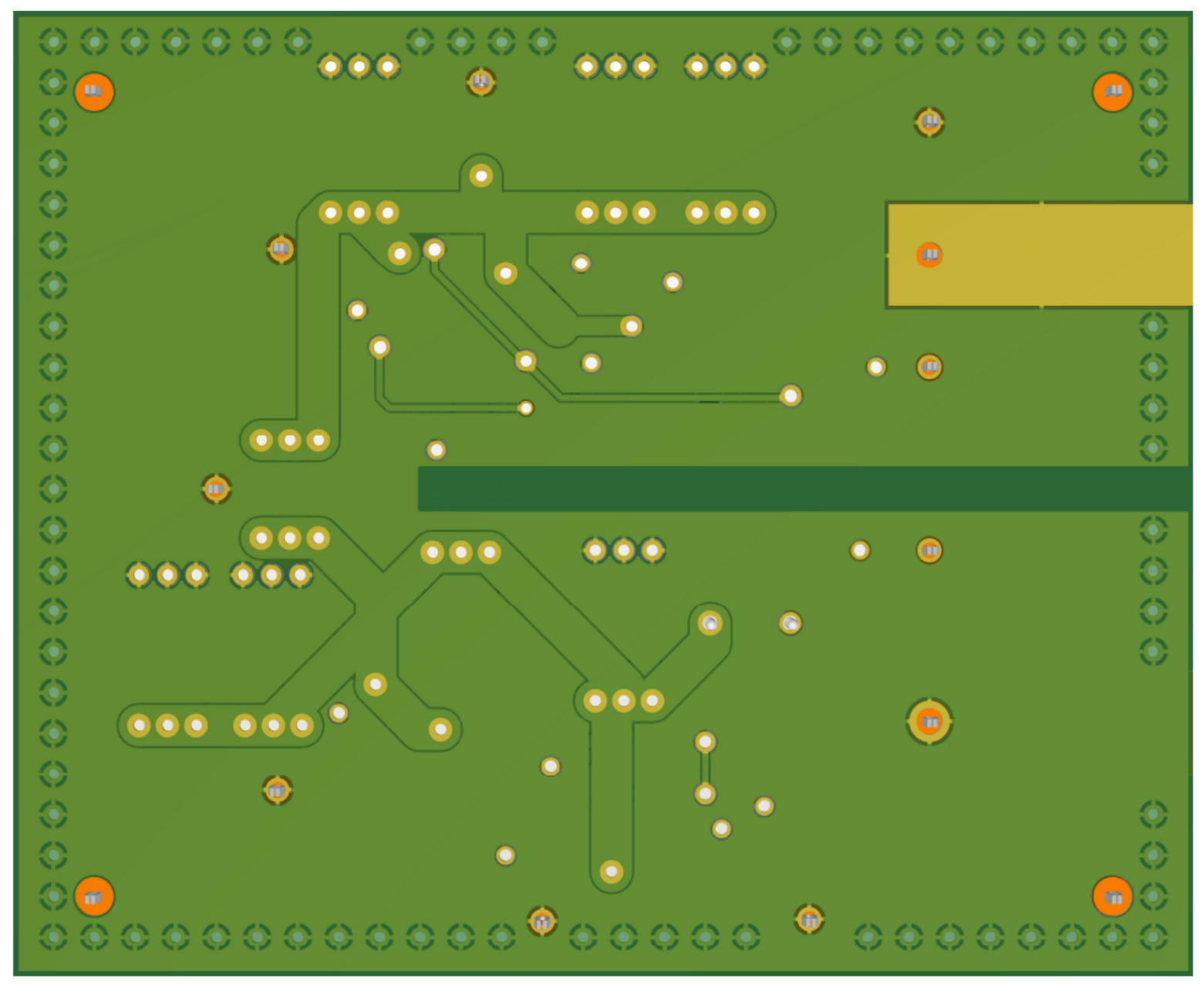




\section{APPENDIX E. CRM SCHEMATIC AND LAYOUT}

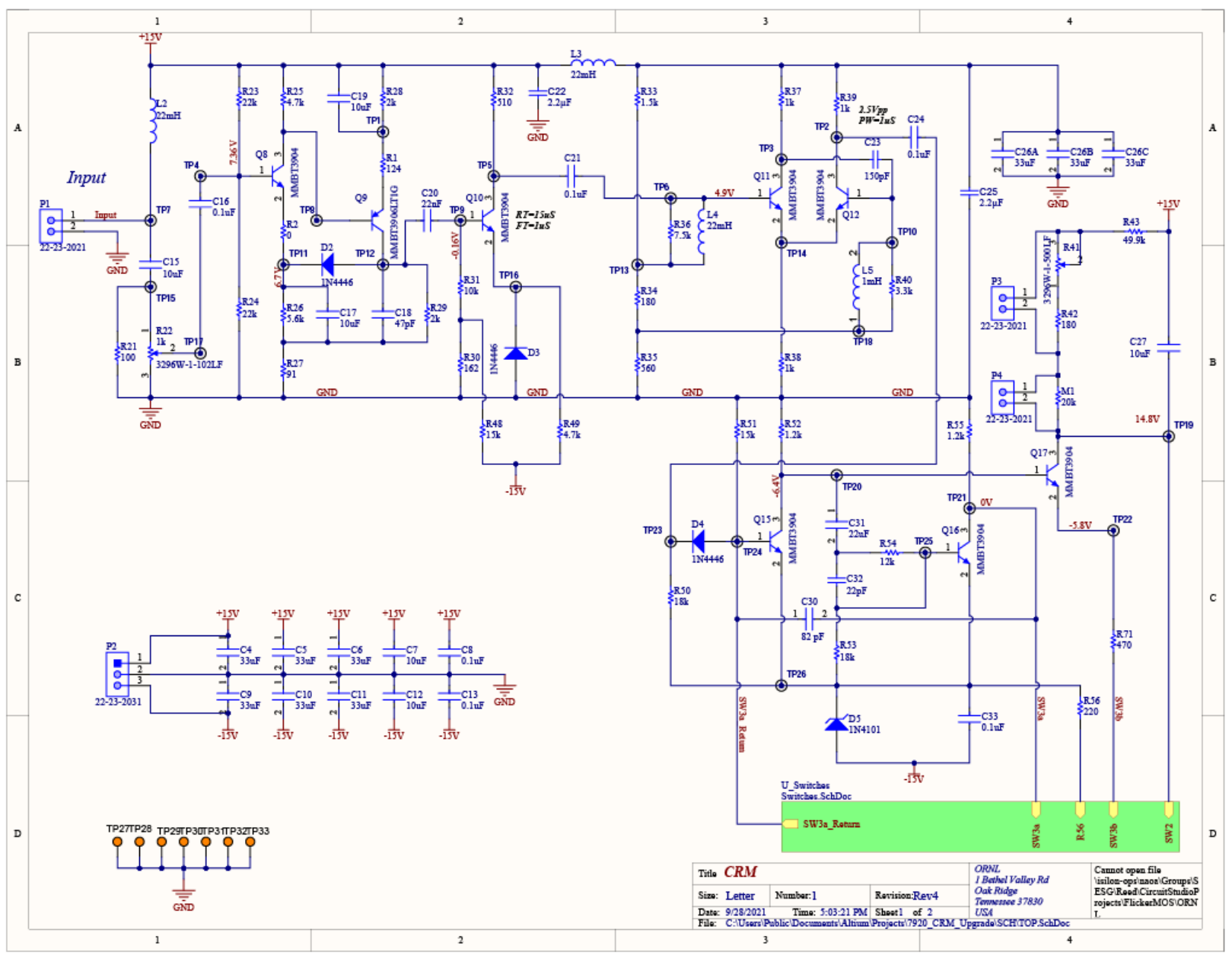



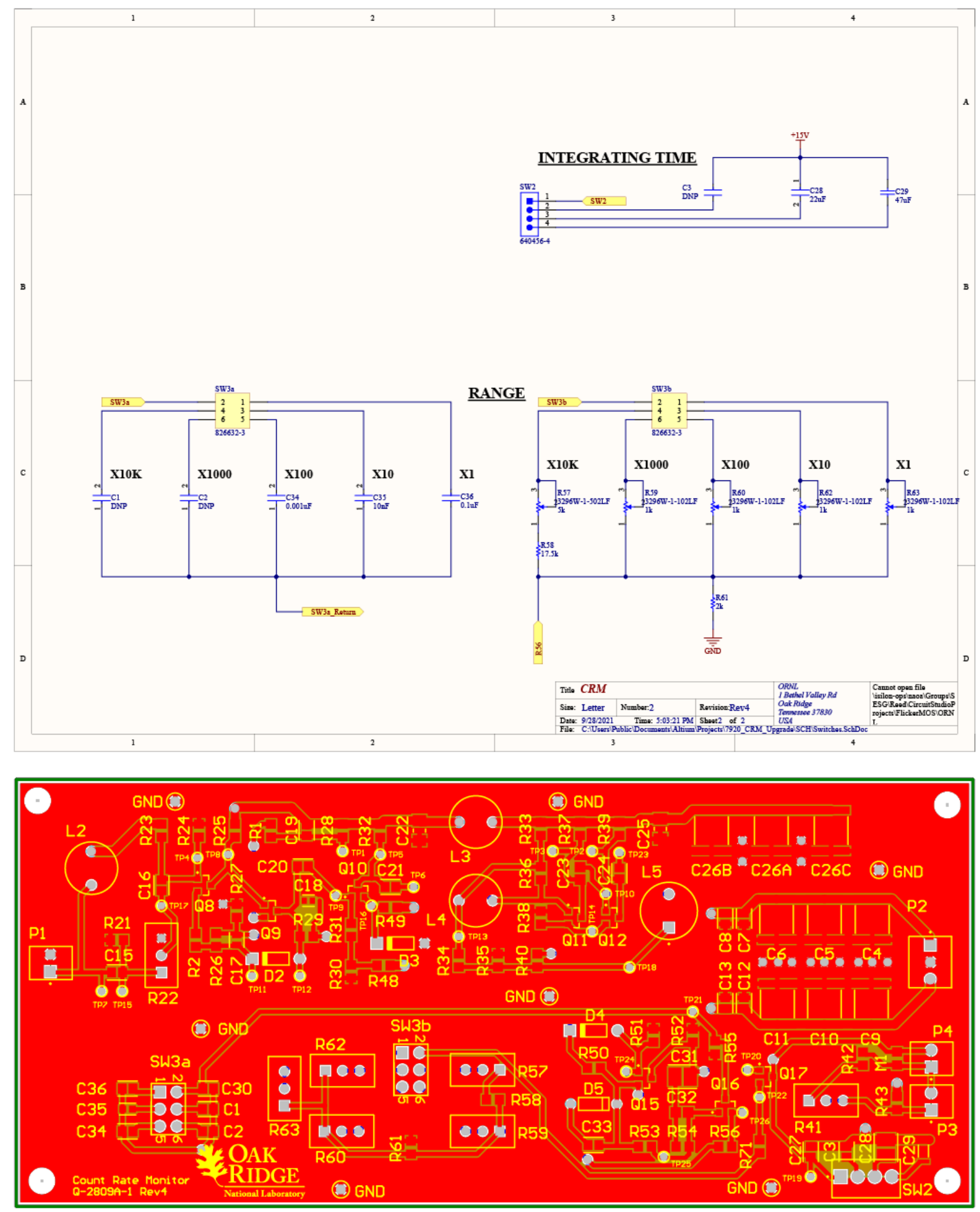

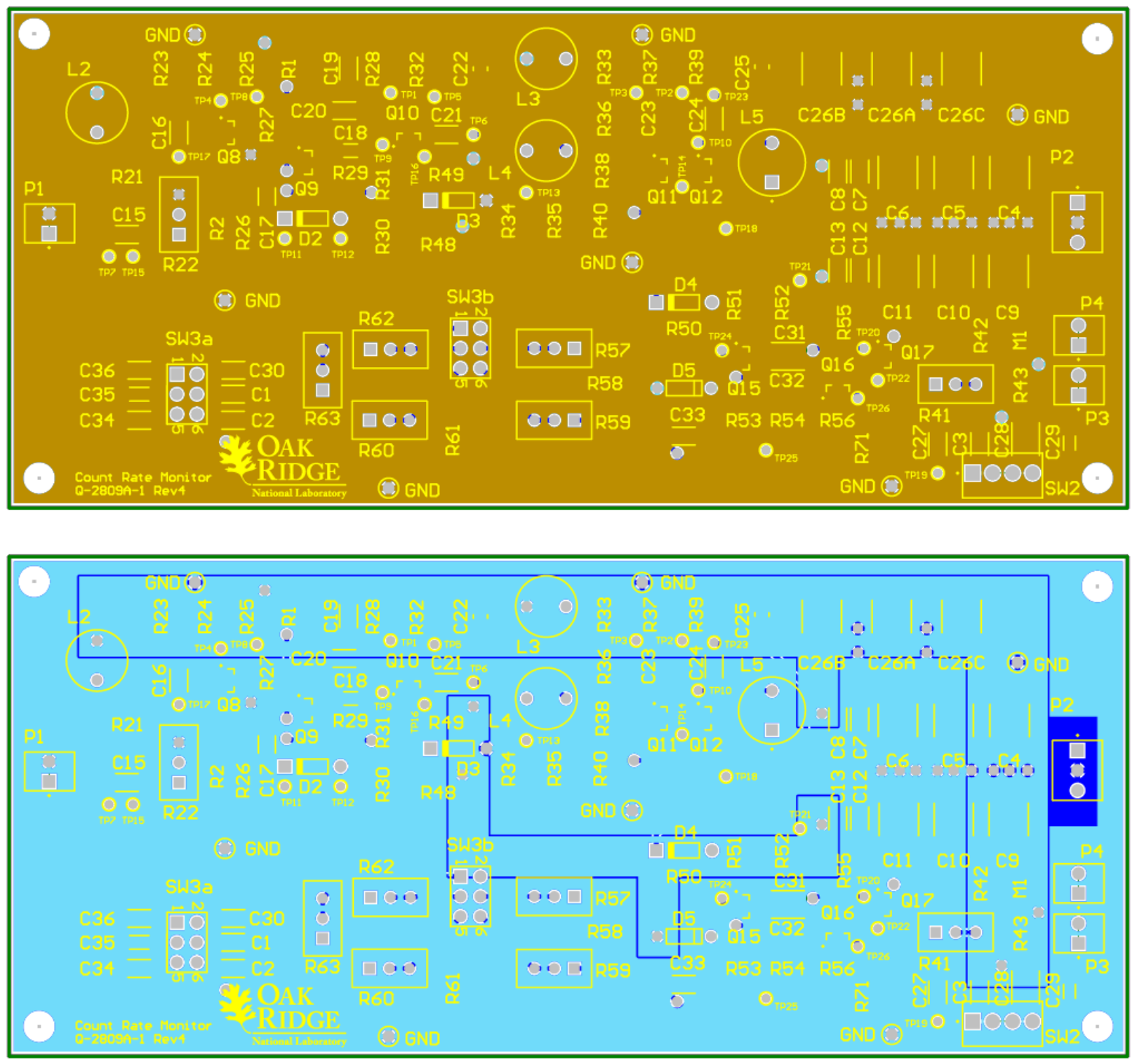

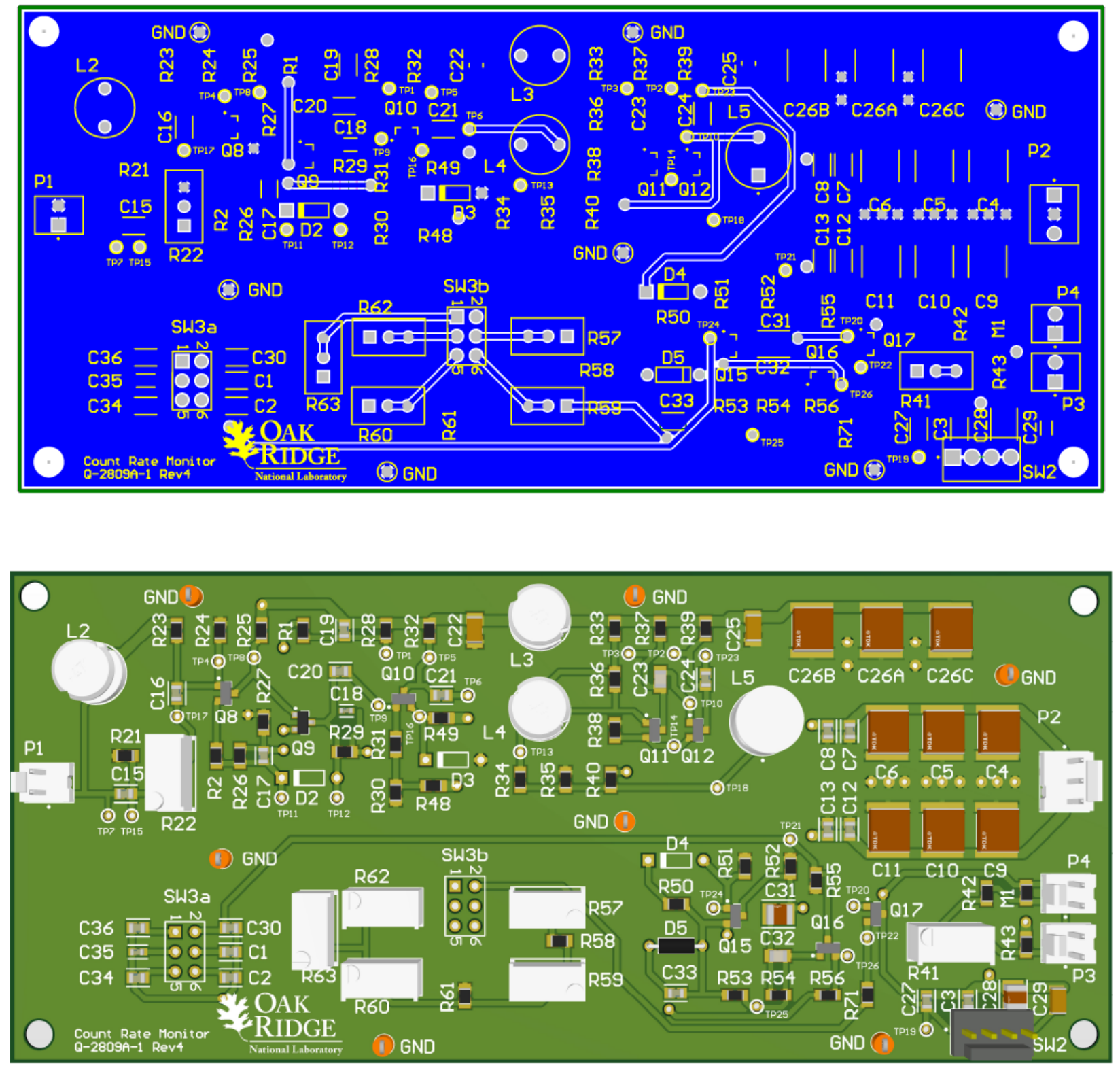


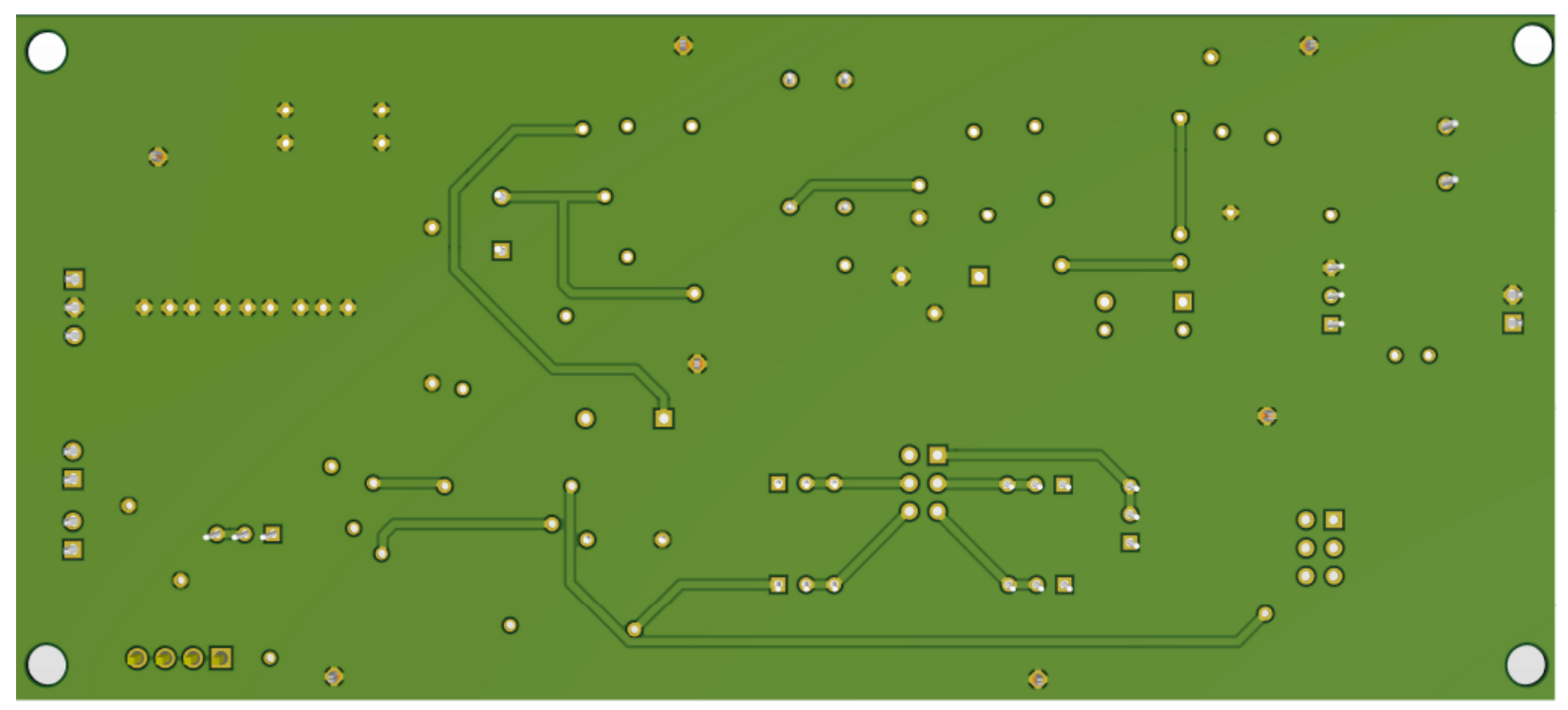

